\title{
The selection of an ideal diet for Ostrea edulis (L.) broodstock conditioning (part B)
}

\author{
Ricardo González-Araya ${ }^{\mathrm{a}, \mathrm{b}}$, Luc Lebrun ${ }^{\mathrm{a}}$, Claudie Quéréc, ${ }^{\mathrm{c}}$ René Robert ${ }^{\mathrm{a},{ }^{*}}$
}

${ }^{a}$ Ifremer, Laboratoire de Physiologie et Ecophysiologie des Invertébrés Marins, Station Expérimentale d'Argenton et, Centre de Brest, Plouzané, France

${ }^{\mathrm{b}}$ Universidad de Los Lagos, Departamento de Acuicultura y Recursos Acuáticos, Osorno, Chile

${ }^{\mathrm{c}}$ Ifremer (LPI), Centre de Brest, Plouzané, France

*: Corresponding author : René Robert, email address : $\underline{\text { Rene.Robert@ifremer.fr }}$

\begin{abstract}
:
Four microalgae species (Rhodomonas salina, Thalassiosira weissflogii, Thalassiosira pseudonana and Pavlova lutheri) were evaluated to estimate their potential as food for Ostrea edulis (L.) reproductive conditioning. Best ingestion and absorption were observed with $R$. salina (3.44 and $1.59 \mathrm{mg} \mathrm{g}^{-1} \mathrm{~h}^{-1}$, respectively), followed by $T$. pseudonana ( 2.75 and $0.98 \mathrm{mg} \mathrm{g}^{-1} \mathrm{~h}^{-1}$ ) and $P$. lutheri $\left(2.40\right.$ and $\left.0.91 \mathrm{mg} \mathrm{g}^{-1} \mathrm{~h}^{-1}\right)$. Oysters fed $T$. weissflogii exhibited the lowest ingestion and absorption values $\left(1.40\right.$ and $\left.0.68 \mathrm{mg} \mathrm{g}^{-1} \mathrm{~h}^{-1}\right)$. Proximate composition (proteins and carbohydrates) and lipid content (fatty acids and sterols) analysed in four main tissues (gonad, digestive gland, muscle and gills) also differed significantly with diet. Protein ranged from $355 \mathrm{mg} \mathrm{g}^{-1}$ in the gonad of oysters fed $P$. lutheri to $837 \mathrm{mg} \mathrm{g}^{-1}$ in gills of oysters fed $T$. weissflogii; whereas carbohydrates ranged from $17.5 \mathrm{mg} \mathrm{g}^{-1}$ in gills of oysters fed $P$. lutheri to $271 \mathrm{mg} \mathrm{g}^{-1}$ in gonads of oysters fed $R$. salina. An overall poor enrichment in total PUFAs across all diets masked some of their potential impact on nutrition. In gonad, however, the major polyunsaturated fatty acids (polar lipid fraction) were EPA $(\approx 19 \%$ for oysters fed $T$. weissflogii and $14 \%$ for those fed $P$. lutheri) and DHA (17\% for oysters fed $P$. lutheri and $15 \%$ for those fed $R$. salina). Sterol contents showed a clear transfer from food to oyster tissues except with $P$. lutheri, from which neither methylpavlovol nor ethylpavlovol (characteristic of Pavlophyceae) were detected in oyster tissues. Histological analysis showed that gametogenesis was active in oysters fed $R$. salina and $T$. weissflogii, whereas only low gonadic development occurred in unfed oysters or those fed $P$. lutheri. $R$. salina is accordingly highly recommended for $O$. edulis broodstock conditioning whereas $P$. lutheri should be excluded.
\end{abstract}

\section{Highlights}

- We study the feeding assessment of four single microalgal species by flat oyster $>$ Best ingestion and absorption were observed with $R$. salina or $T$. weissflogii $~ I n$ gonad, the major polyunsaturated fatty acids (polar lipids) were EPA and DHA $>$ A transfer of sterols from food to oyster tissues occurred except with $P$. lutheri $\triangleright$ Gametogenesis was very active in oysters fed $R$. salina or $T$. weissflogii

Keywords: Ostrea edulis; Conditioning; Algal diets; Ingestion; Absorption; Biochemical composition 
Broodstock conditioning is a key step in the process of rearing bivalves under standardized conditions. Its success has often been estimated in terms of the quality of bivalve eggs and larvae produced. Thus, initial egg lipid contents have been found to be positively correlated with either larval survival (e.g., Mercenaria mercenaria and Crassostrea virginica: Gallager and Mann, 1986; Pecten maximus: Le Pennec et al., 1991) or larval growth (O. edulis: Helm et al., 1973). Although temperature has been considered to be the main environmental factor regulating bivalve reproduction (e.g., C. gigas: Fabioux et al., 2005; Mytilus galloprovincialis: Fearman and Moltscchaniwskyj, 2010); feeding (i.e., the amount of food supplied) also seems to be an important factor for increasing fecundity (e.g., C. gigas: Chavez-Villalba et al., 2003; Argopecten purpuratus: Martinez et al., 2000). In contrast, the influence of the relative food value of different phytoplankton species (nutritional quality) on mollusc gonadic development has been very little explored, especially in $O$. edulis. The pioneer works of Frolov and Pankov (1992) and Millican and Helm (1994) provided relevant information in this field but only a few studies (Berntsson et al., 1997) have been carried out since. Indeed the appearance in France in the 1970-1980s of epizooties of Marteilia refringens (Comps, 1970) and Bonamia ostreae (Comps et al., 1980) and their progressive extension throughout Europe (see review in Laing et al., 2005) led to the collapse of $O$. edulis culture and research then focused more effort on recently introduced species (e.g., C. gigas: Helm and Millican, 1977; Robert et al., 1982, and R. philippinarum: Helm, 1990; Utting and Spencer, 1991).

In Europe, particularly France and Spain, O. edulis remains an emblematic species and attempts to develop "resistant strains" have been made in both countries (Naciri-Graven et al., 1988; Montes et al., 2003; Lallias et al., 2010). Moreover, such interest in flat oyster cultivation is now increasing in France due to high C. gigas juvenile mortalities (Samain and McCombie, 2007; Pernet et al., 2010).

To allow $O$. edulis genetic improvement through selection, the reliability of hatchery methods for this species needs to be improved. As already pointed out, conditioning is an important step in hatchery production of molluscs and particular attention needs to be paid to flat oyster feeding during this stage because hatchery-conditioned broodstock has been found to have lower fecundity than wild stock (Helm et al., 1991). We had already made an initial study to look for an ideal diet for O. edulis (Gonzalez-Araya et al., 2010). This work compared four monospecific microalgal diets based on ecophysiological and biochemical approaches, and assumed that the best microalgae should be those that were highly ingested, digested, assimilated and efficiently allocated to the reproductive compartment. The present study was designed to provide complementary information by testing the influence of four more microalgae on $O$. edulis consumption, ingestion, assimilation and reproduction.

\section{Material and methods}

The techniques used in this study were previously detailed in González-Araya et al. (2010), so only a brief outline will be given here.

\section{Experimental design}

In August 2008, O. edulis aged 18 months $(\approx 5 \mathrm{~cm}$ length and $0.5 \mathrm{~g}$ flesh dry weight), originating from Bay of Quiberon (South Brittany, France) were submersed, at $5 \mathrm{~m}$ depth, for 1 month, in mesh bags tied to trestles in the Bay of Brest. They were then returned to the quarantine area of the Argenton hatchery, where they were maintained at $14{ }^{\circ} \mathrm{C}$ for an additional month, during which they were treated for a week with chloramphenicol at $8 \mathrm{mg} \mathrm{l}^{-1}$ to limit any development of vibrios. Thereafter, seawater temperature was increased by $1{ }^{\circ} \mathrm{C}$ weekly and, at beginning of October 2008, the flat oysters were transferred to translucent 50I tanks where they were distributed homogeneously (30 oysters per tank, corresponding to 
an equivalent biomass of $\approx 1 \mathrm{~kg}$ total weight and $16 \mathrm{~g}$ dry flesh weight). During this preconditioning period oysters were fed a mixed diet of T. Iso and Chaetoceros gracilis used routinely in Argenton to feed most of mollusc at different stages of development (Ben Kheder et al., 2010). Triplicate tanks were set up for each of the four single diet species tested here. Oysters were maintained in a flow-through system at $19{ }^{\circ} \mathrm{C}$ and fed constantly at $900 \mu \mathrm{m}^{3} \mathrm{\mu l}^{-1}$ or unfed (only receiving continuously $1 \mu \mathrm{m}$-filtered-seawater). Four different microalgae were tested as mono-specific diets at the same biovolume (measured daily and accordingly including variation in cell volume) : Rhodomonas salina (mean volumetric size $160 \mathrm{\mu m}^{3}$, mean dry weight $130 \mathrm{pg} \mathrm{cell}^{-1}$, strain CCAP 978/24), Thalassiosira weissflogii $\left(900 \mathrm{\mu m}^{3}, 250\right.$ pg cell ${ }^{-1}$, strain CCAP 1085/1), Thalassiosira pseudonana $\left(40 \mathrm{\mu m}^{3}, 35 \mathrm{pg}\right.$ cell $^{-1}$, strain CCAP 1085/3) and Pavlova lutheri $\left(40 \mu^{3}, 20 \mathrm{pg} \mathrm{cell}^{-1}\right.$, strain CCAP 931/1). The choice of these species was based on their frequency of utilization in different mollusc commercial hatcheries worldwide (Robert and Trintignac, 1997; Borowitzka, 1997). Ingestion and absorption of the different microalgae were studied according to Beiras et al. (1994) over six consecutive weeks. It was hypothesized that the microalgae species that was best absorbed by oysters represented the best potential diet; hence, we tested this hypothesis by examining nutrient biochemical allocation in the gonads in the polar fraction compared with other tissues to control potential reproductive specificity.

Microalgae were grown in standard batch culture, based on the step-by-step method (Robert et al., 2004). Cultures grown in 300-I cylinders were used as feed for oysters when they attained the late logarithmic phase after 3-5 days. Conwy medium (Walne, 1966) was used at $1 \mathrm{ml} \mathrm{l}^{-1}$ except for $R$. salina, which was cultivated on a double dose of nutrients to improve growth.

\section{Ecophysiological measurements}

Ingestion was estimated by measuring algal concentration twice a day using an electronic coulter counter (Multisizer 3 ) at the inlet $\left(\mathrm{C}_{i}\right)$ and outlet $\left(\mathrm{C}_{0}\right)$ of each tank with consumption $\mathrm{C}$ $=C_{i}-C_{0}$. For all diets, pseudofaeces production $(P F)$ was $<10 \%$ and considered as nil so that consumption $\approx$ ingestion $(C \approx I)$.

Tanks were drained and oysters cleaned three times a week (Monday, Wednesday and Friday) and daily faeces production, established over precise 24-h periods, was accordingly measured on the two other days: Tuesday for $R$. salina and $T$. weissflogii and Thursday for the other two diets. Faeces samples were collected onto a $450{ }^{\circ} \mathrm{C}$ pre-combusted GF/C (Glass Filter, type C : grade $1.2 \mu \mathrm{m}$ ) filter using a vacuum pump and washed with ammonium formate solution. Faeces total weight was measured after drying at $75^{\circ} \mathrm{C}$ and the Organic Matter fraction (\% OM) calculated by the difference after combustion at $450{ }^{\circ} \mathrm{C}$ for $4 \mathrm{~h}$. The procedure was similar for microalgae, for which $25 \mathrm{ml}$ of culture were filtered for each sample.

For each diet, the coefficient of variation was $<10 \%$ and the data were accordingly pooled to express the mean faeces production over the entire experimental period. Under such conditions, absorption $(A)$ was defined as $A=I$ (Ingestion) $\times$ ae (absorption efficiency) and ae was defined as : ae $=100 \times\left(\mathrm{OM}_{A}-\mathrm{OM}_{F} /\left[\left(1-\mathrm{OM}_{\mathrm{F}}\right) \times \mathrm{OM}_{\mathrm{A}}\right]\right.$, where $\mathrm{OM}_{\mathrm{A}}$ is the microalgae relative organic content and $\mathrm{OM}_{\mathrm{F}}$ the faeces relative organic content (Conover, 1966).

\section{Biochemical analysis}

At the beginning and end of the experimental period, 15 oysters per feeding condition were dissected to sample four different organs separately: gonads $(G n)$, digestive gland $(\mathrm{Dg})$, adductor muscle $(\mathrm{Am})$ and gills $(\mathrm{G})$. For each diet, three pools were prepared of each of the four organs, each pool containing the tissues of five oysters; these were then stored at -80 ${ }^{\circ} \mathrm{C}$ for a period of up to 6 months prior to analysis.

Aliquots of the homogenate were analysed separately for protein (Lowry et al., 1957), carbohydrate (Dubois et al., 1956), fatty acids and sterols (Folch et al., 1957). Fatty acids were analysed after transesterification with BF3 according to Marty et al. (1992) and 
Delaporte et al. (2006), whereas sterols were evaluated after transesterification with sodium methoxide (Eder et al., 1992; Soudant et al., 2000). Fatty acids and sterols were identified by comparing their retention time with standards (23:0 for FA and cholestane for sterols). In the present study, we initially only planned to report the fatty acids of the polar lipid fraction, as we did in our sister work (Gonzalez et al., 2010), because they correspond to real assimilation. However, we extended our analysis to some of the main fatty acids of the neutral lipid fraction because this additional data was useful to improve our understanding of the fate of these compounds, as mentioned in the discussion.

\section{Gametogenesis survey}

At the beginning and end of the experimental period, 15 oysters per diet were frozen and stored at $-80{ }^{\circ} \mathrm{C}$ until gonad histological analysis. Gamete activity was assessed using Mann's maturity index (Mann, 1979) to classify oysters into five categories on a scale of 0-4 ranging from inactivity (0) to spent (4).

\section{Statistical analyses}

After logarithmic transformation (log10 $\left.\left[\mathrm{x}_{i}\right]\right)$ of ingestion and absorption data, and angular transformation of percentage data by the function [arcsin (square root $x_{i} / 100$ )] for biochemical composition, statistical analyses were carried out using SIGMAPLOT software (version 11.0). Significant differences were detected between the means at the 5\% threshold using ANOVA and a posteriori multiple comparison test of the means (Pairwise Holm-Sidak Method).

\section{Results}

Effects of food on physiological parameters

Cumulative mortality remained low in all diets $(2 \%)$ meaning that they could be objectively compared.

The highest ingestion rate reached by 0 . edulis was $3.44 \pm 0.22 \mathrm{mg} \mathrm{g}^{-1} \mathrm{~h}^{-1}$, achieved when they were fed Rhodomonas salina. In contrast, Thalassiosira weissflogii led to low ingestion, with a mean value of $1.40 \pm 0.17 \mathrm{mg} \mathrm{g}^{-1} \mathrm{~h}^{-1}$. Oysters fed $T$. pseudonana or Pavlova lutheri showed intermediate positions, with mean ingestion rates of $2.75 \pm 0.22$ and $2.41 \pm 0.30 \mathrm{mg}$ $\mathrm{g}^{-1} \mathrm{~h}^{-1}$, respectively.

Similarly, flat oysters fed $R$. salina exhibited a significant higher absorption value $(A=1.62 \pm$ $\left.0.04 \mathrm{mg} \mathrm{g}^{-1} \mathrm{~h}^{-1}\right)$ than those fed the other three diets $(\mathrm{p}<0.001)$. Despite $R$. salina and $T$. weissflogii showed similar absorption efficiencies (ae $=47 \%$ and $51 \%$ respectively), $R$. salina absorption was twice as high as that of $T$. weissflogii $\left(A=0.68 \pm 0.02 \mathrm{mg} \mathrm{g}^{-1} \mathrm{~h}^{-1}\right)$. In contrast oysters fed $T$. pseudonana or $P$. lutheri showed similar absorption values and absorption efficiencies ( $A=0.98 \pm 0.10$ and $0.91 \pm 0.11 \mathrm{mg} \mathrm{g}^{-1} \mathrm{~h}^{-1}$, ae $=33-34 \%$, respectively). When flat oysters were supplied with feed composed of these two last microalgae, no significant differences were recorded in ingestion, absorption and assimilation values ( $p>>0.05)$.

\section{Diet composition}

Diatoms and flagellates differed in their fatty acid and sterol contents (Table 1). Whereas $R$. salina and $P$. lutheri were rich in $22: 6(n-3)$, which represented 8 to $11 \%$ of total fatty acids, respectively (vs. 3.5 to $4.5 \%$ for the Thalassiosira). Diatoms were characterized by high EPA concentration (14.5 to $20.5 \%$ ), but $20: 5(n-3)$ content was surprisingly the highest in P. lutheri 
(23.5\% vs. $9.5 \%$ in $R$. salina). R. salina was also particularly rich in $18: 2(n-6)$ (18\% vs. 0.5 to $2.5 \%$ for the three other microalgae; $p=0.011$; Table 1). In contrast, $R$. salina was poor in $16: 1(n-7)$, with only $0.7 \%$ vs. 16 to $20 \%$ for the other three diets and accordingly such overall differences were significant $(p=0.036)$. However, no mean row differences were found by use of a multiple posteriori test. Arachidonic acid (AA; 20:4 (n-6)) was highly variable between species without any overall trend. Thus, with only $0.2 \%$ AA $T$. weissflogii was the microalga with the poorest level, contrasting with the other Thalassiosira (pseudonana), which had the highest content $(9.4 \%)$. AA represented $2.4 \%$ in $R$. salina but was a fifth of this amount in $P$. lutheri $(\approx 0.5 \%)$. Lastly, with values ranging from 0.2 to 0.9 , the DHA/EPA ratio did not fluctuate widely (Table 1 ).

With around $79 \%$ of total sterols, T. weissflogii and T. pseudonana were rich in 24-methylencholesterol compared with the two flagellates (vs. 0 to $2 \%$ ). Despite lower contents (4.4 to $6 \%$ ), cholesterol was also characteristic of the diatoms (vs. $0.4 \%$ for both flagellates) (Table 1). R. salina was characterized by a high brassicasterol content $(97 \%)$; whereas, this sterol was inexistent in the other diets tested here. P. lutheri contained specific sterols, including methylpavlovol (36\% of total sterols), ethylpavlovol $(16 \%)$, methylporifera $(14 \%)$ and $\beta-$ sitosterol $(12 \%)$, that were not detected in the other diets (Table 1).

\section{Effect of food on oyster biochemical composition}

Mean gonad protein content increased from $335 \mathrm{mg} \mathrm{g}^{-1}$ at the beginning of the experiment to 470 to $501 \mathrm{mg} \mathrm{g}^{-1}$ at the end in oysters fed all diets except $P$. lutheri, which led to no significant rise $\left(355 \mathrm{mg} \mathrm{g}^{-1}\right)$. After 6 weeks, the highest gonad protein content was observed in oysters fed $R$. salina $501.5 \pm 178 \mathrm{mg} \mathrm{g}^{-1}$, but differences with the other diets were not significant ( $p=0.43$ ); (Fig.1a). Protein increase was also independent of diet in flat oyster muscle (802-815 mg g ${ }^{-1}$ vs. $718 \mathrm{mg} \mathrm{g}^{-1}$ initially; $\left.p=0.63\right)$, gills $\left(692-837 \mathrm{mg} \mathrm{g}^{-1}\right.$ vs. $734 \mathrm{mg} \mathrm{g}^{-1}$ initially; $p=0.32$ ) and digestive gland (476-608 $\mathrm{mg} \mathrm{g}^{-1} \mathrm{vs.} 449 \mathrm{mg} \mathrm{g}^{-1}$ initially; $p=0.18$ ) (Fig. 1a).

There was no enrichment in carbohydrate in oyster gonad, gills or digestive gland with any of the diets $(0.59>p>0.13)$ (Fig. 1b). Oysters did, however, show carbohydrate accumulation in muscle $(p<0.001)$ with all the diets except $P$. lutheri: levels increased from an initial $13.9 \pm$ $2 \mathrm{mg} \mathrm{g}^{-1}$ to $38.9 \pm 5 \mathrm{mg} \mathrm{g}^{-1}$ with $R$. salina; whereas, they only reached $17.5 \pm 7 \mathrm{mg} \mathrm{g}^{-1}$ with $P$. lutheri (Fig. 1).

Whatever tissues were analyzed, the main polar fatty acids found over all diets were 16:0, 18:0, $20: 4(n-6), 20: 5(n-3), 22: 2 \mathrm{j}$ and $22: 6(n-3)$ which represented $\approx 50-65 \%$ of total fatty acids (gonad $=62 \%$ : Table 2), (digestive gland $=64 \%$ : Table 3 ), $($ muscle $=55 \%$ : Table 4 ) gills $=52 \%$ : Table 5 ). These specific fatty acids represented initially $65-67 \%$ of total FA regardless oyster tissues.

Neither total fa nor specific fa enrichment of the gonad was found (Table 2). Thus, no significant differences between diets were found for 16:0 $(p=0.99)$, with values ranging from 18.3 to $20.2 \%$ after six weeks of conditioning, compared with $20.7 \%$ at the beginning of the experiment (Table 2). Similarly no significant 18:0, 20:4 (n-6), 20:5(n-3), 22:2j, 22:6(n-3), values fluctuations were noted over time $(p=0.83 ; p=0.10 ; p=0.88 ; p=0.89 ; p=0.98$ respectively: Table 2). In contrast, significant 20:2 (n-6) enrichment occurred when oysters were fed $R$. salina $(1.3 \%)(p=0.03)$ (Table 2$)$. It was the only fa exhibiting significant differences over time in the gonad when values were expressed as relative content. When considering absolute content and beyond the main fatty acids only a significant 20:4 (n-6) increment was noted in oysters fed $T$. pseudonana.

There was no specific fatty acid transfer to the gonad because the trends found for the main fatty acids in the gonad were similar to those in the digestive gland except for $20: 4(n-6)$, which accumulated when oysters were fed T. pseudonana (Table 3 ). When considering absolute content in minor fatty acids, an enrichment in 20:2(n-6) occurred when oysters were fed $R$. salina (Table 3); whereas, a decrease in 22:5(n-6) was noted for those fed $T$. weissflogii and T. pseudonana contrasting with the enrichment found with $P$. lutheri (Table 3 ). Most of the other minor fatty acids in the digestive gland showed differences when considering absolute values but no clear trend can be seen (Table 3). A similar overall 
situation was also found for the main fatty acids in muscle except for 16.0 , whose absolute values decreased $(p<0.001)$ with all diets (Tables 4$), 20: 4(n-6)$ and 22:2j which increased in oysters fed $T$. pseudonana and T. weissflogii respectively(Table 4). As for digestive gland some specific trends can be seen in minor fatty acids when considering absolute values. Thus an increase in 16:1(n-7), 18:1(n-7), 18:2(n-6) was noted in muscle when oysters were fed $T$. weissflogii, and $R$. salina contrasting with the decrease observed in 16:3(n-3) for all diets (Table 4). A similar overall situation was also found for the main fatty acids in gills except for 20:4(n-6) whose absolute value increased when oysters were fed $T$. pseudonana (Table 5). Similar trends as those reported in muscle can be seen in minor fatty acids when considering absolute values. Thus an increase in 16:1(n-7), 18:1(n-7), 18:2(n-6) was also noted in gills when oysters were fed $T$. weissflogii, and $R$. salina. (Table 5 ). In contrast a specific increase in 22:5(n-6) occurred with $P$. lutheri.

In the unfed oysters, no significant differences $(p>0.05)$ were found in main polar fatty acid composition except for 16:0 in most of tissues at the end of the 6-week experiment (Table 6). Because no gonad development occurred in unfed oysters, it was impossible to separate this organ from the mantle and no data were therefore available on this tissue at the end of conditioning (Table 6).

When fed different microalgae, neutral fatty acid contents followed similar trends to polar fatty acids in all oyster tissues including gonad (Fig. 2). When oysters were fed $T$. weissflogii or T. pseudonana, an accumulation of 20:5(n-3) was noted but depletion of 22:6(n-3) was observed in oysters fed the same microalga. An accumulation of $20: 4(n-6)$ was only observed in oysters fed $T$. pseudonana and, to a lesser extent, in oysters fed $R$. salina. No accumulation of 22:6(n-3) in gonad was observed in oysters fed $R$. salina, whatever fraction (neutral or polar) of lipids was analysed (Fig. 2).

Cholesterol allocation in all oyster tissues were not related to diet species because its content remained globally constant (Table 7) even with $T$. weissflogii and $T$. pseudonana supply, however rich in this sterol (Table 1). In contrast, in oysters fed T. pseudonana, 24Methylen-cholesterol enrichment occurred in all tissues except digestive gland (Table 7). Such pattern was also found with $T$. weissflogii, however, to a lesser extend (Table 7). There was accordingly a clear food imprint for 24-Methylen-cholesterol that is the main sterol in both diatoms (80\%: Table 1). When oysters were fed $R$. salina, brassicasterol enrichment seemed to occur in all tissues, doubling the concentrations, from $\approx 20 \%$ to $35-45 \%$ (Table 7 ) but such differences were not significant due to high variability in tissues samples of oysters fed $R$. salina ( $C V=10-15 \%)$. On the other hand, campesterol allocation seemed to be more erratic, with a significant increase in gonad and gills of oysters fed $T$. weissflogii but an enhancement in the digestive gland of oysters fed T. pseudonana (Table 7). Lastly, when oysters were fed $P$. lutheri, no assimilation or incorporation of specific $P$. lutheri sterols (methylpavlovol and ethylpavlovol) was observed in any of the tissues which contrasted with the enrichment of $\beta$-sisterol in the gonad and gills (Table 7).

\section{Gonad development}

At the beginning of experiment, $33 \%$ of oysters had recently spawned (stage $4: 33 \%$ ) or were sexually inactive (stage 0: 50\%), while only 17\% were at the initiation stage of gametogenesis (stage 1) (Table 8). At the end of experiment, a clear effect of the diets on gametogenesis evolution was visible. Gametogenesis had occurred more rapidly when oysters were fed $R$. salina and $T$. weissflogii, than when they were fed $T$. pseudonana and $P$. lutheri. When oysters were fed $R$. salina at least $50 \%$ of the population became ripe, while $40 \%$ spawned (Table 8 ). When fed T. weissflogii, $61 \%$ of the population became ripe during the experiment, while $20 \%$ were still in development (Table 8 ); thus, on week 6 , a total of 1.5 million larvae were collected from oysters fed $R$. salina and 1 million from oysters fed $T$. weissflogii. Among oysters fed T. pseudonana $48 \%$ were ripe, but $25 \%$ of the population were still inactive (Table 8 ). In contrast, among oysters fed $P$. lutheri, only $7 \%$ of individuals were ripe, $43 \%$ were developing, and inactive individuals represented $40 \%$ of the population (Table 8). No larval release was recorded during the experimental period in either of these last two diets. 


\section{Discussion}

Impact of diets on physiological responses

The four microalgae differed significantly in their value for Ostrea edulis broodstock conditioning. First, they had a differential influence on response of flat oyster nutritional physiology. Ingestion of oysters fed $R$. salina $\left(3.4 \mathrm{mg} \mathrm{g}^{-1} \mathrm{~h}^{-1}\right)$ was double that of oysters fed $T$. weissflogii $\left(1.4 \mathrm{mg} \mathrm{g}^{-1} \mathrm{~h}^{-1}\right)$. This discrepancy could be explained by the difference in microalgae cell size between these species, which have a six fold volume difference: 900 $\mu \mathrm{m}^{3}$ vs. $160 \mathrm{\mu m}^{3}$. It may also explain the intermediate position occupied by $T$. pseudonana and $P$. lutheri (2.4 to $\left.2.8 \mathrm{mg} \mathrm{g}^{-1} \mathrm{~h}^{-1}\right)$, both of which have a lower cell size $\left(40 \mu \mathrm{m}^{3}\right)$. Nevertheless, it has been reported that, among food particles of similar size, Crassostrea gigas larvae showed a target preference for Chaetoceros calcitrans forma pumilum (RicoVilla et al., 2006). Moreover, it has been reported that external organic components of the diatom Coscinodiscus perforatus act as a major selection cue for Pecten maximus (Beninger and Decottignies, 2005). Lastly, epicellular molecules, such as lectins, have been showed to play a significant role in food selection of Mytilus edulis (Espinosa et al., 2010). Food selection seems to be an active process and, in the present case, $O$. edulis clearly shows a greater affinity preference for $R$. salina.

A similar trend was observed for absorption, but there was also high absorption efficiency with $T$. weissflogii. (51\%). Although the oysters fed $R$. salina showed the best ingestion and absorption of the study, the values remained lower than those previously reported with $C$. gracilis and S. marinoï $\left(\approx 5 \mathrm{mg} \mathrm{g}^{-1} \mathrm{~h}^{-1}\right.$ : González-Araya et al., 2010). Absorption efficiency (ae\%) ranged from 33 to $51 \%$, while those obtained with the four other microalgae tested in our sister study ranged from 19 to $46 \%$ (González-Araya et al., 2010). It is interesting to note that, whichever of the eight different species the microalgae was supplied, $O$. edulis absorption efficiency on single diets was lower than that achieved with a mixed diet, as reported by Savina and Pouvreau (2004) who observed $80-90 \%$ ae with Glycymeris glycymeris and Phaphia romboïdes. It is also notable that high ae has been reported in tropical mollusc species fed single-species diets: $70-90 \%$ ae in Pinctada maxima fed T- Iso or Dunaliella primolecta and $80-90 \%$ ae in Pinctada margaritifera fed the same diets (Yukihira et al., 1998).

\section{Impact of diets on biochemical responses}

In bivalves, mantle, digestive gland and adductor muscle tissues are considered to serve for storage and translocation of protein and glycogen, lipids and proteins, respectively (Barber and Blake, 1985; Saucedo et al., 2002). Thus, the reproductive cycle of a bivalve can be divided into two processes: storage accumulation (generally glycogen) and gametogenesis (Pouvreau et al., 2006), which is achieved by using previously accumulated reserves and/or available food. The seasonal changes in energy storage and depletion in relation to gametogenesis are well documented (Bayne et al., 1982, Barber and Blake, 1985). Indeed, the adductor muscle of pectinids is known to be an important energy reserve site, and its utilization is associated with reproductive effort (Soudant et al., 1996). The utilization of carbohydrate from the $O$. edulis adductor muscle as source of energy was not clearly shown in the present study. Nevertheless, at the end of experiment, higher carbohydrate concentrations were recorded in gonads of oysters fed $R$. salina, which were also the oysters with the best gonadic development. For the other tissues analyzed, there were no statistical differences in either protein and carbohydrate contents during conditioning $(p>0.05)$ regardless of diet. In the present study, conditioning was carried out from September 2008 to December 2008, and these results could be explained by specific environmental effects prior to oyster collection. In our experiment, despite a pre-conditioning period in which the oysters 
were exposed to low temperature and food conditions just after harvest, it is likely that reserves from summer storage remained in most tissues and that these contributed to the initial proximate values measured. This idea is in agreement with results already reported in O. edulis (Gabbot and Walker, 1971) C. gigas (Delaporte et al., 2006) and Pinctada mazatlanica (Saucedo et al., 2002), for which the apparent glycogen ( $80 \%$ of carbohydrate contents) and protein increase were observed from January to July, with a second minor peak from August to October.

Polyunsaturated fatty acids (PUFAs) EPA (20:5(n-3)) and DHA (22:6(n-3)) have been shown to be essential for a wide variety of molluscs, as well as prawns and fish larvae (Volkman et al., 1989). Thus, phytoplankton species deficient in EPA and DHA have been reported to be poor food value for C. gigas spat (Langdon and Waldock, 1981). Moreover, it is likely that DHA plays a major structural and functional role in the cell membranes involved in oogenesis and embryogenesis (Soudant et al., 1996) in P. maximus broodstock. The specific role of 20:5(n-3) has been found to be related to energetic functions during embryogenesis of Crassodoma gigantea (Whyte et al., 1992) and P. maximus larvae (Delaunay et al., 1993; Soudant et al, 1998).

For O. edulis broodstock fed diets rich in PUFAs, a transfer of these fatty acids to their larvae was reported by Frolov and Pankov (1992). Lastly, many studies have documented relations between the fatty acid profile of the diet and that of the gonad or larvae contents (Knauer and Southgate, 1997; Caers et al., 2000; Flores-Vergara et al., 2004). The results of the present study differ in that the fatty acid profiles of main tissues did not show a clear correlation with the diets as it has been shown in our previous work with four other microalgae (Fig. 3; Gonzalez et al., 2010). These results were unexpected, because fatty acid composition in microalgae is generally specific. Here $R$. salina and $P$. lutheri exhibited high DHA contents, whereas the two Thalassiosira species showed high EPA values. Despite this specific composition, no accumulation of DHA above the initial contents was recorded in any organs of oysters fed $R$. salina or $P$. lutheri. Initial DHA contents seemed accordingly to be sufficient to cover the needs of the oysters, or had already reached a maximum level of accumulation in the gonads. Broodstock for this experiment were collected at the end of summer, and it is possible that the second peak of phytoplankton in the natural environment contributed to the PUFAs already present in oyster gonads in their initial state in our experiment. This idea is supported by data from the phytoplankton survey network (REPHY, 2011), which show a second peak of phytoplankton at the end of summer 2008 in Bay of Quiberon (Brittany, France).

Indeed it is has been reported that proportions of 22:6(n-3) and 20:5(n-3) from neutral and polar lipids of artificially conditioned oysters are generally lower than those developing in the natural environment (Soudant et al., 1999). In our study, it is noteworthy that initial DHA contents at the beginning of autumn conditioning (16\%: Fig. $2 \mathrm{~b}$ ) were similar to DHA values recorded at the end of spring conditioning in oysters fed T-Iso (16\% vs $13.5 \%$ for spring initial value: Fig. $3 b)$ known to be particularly rich in 22:6(n-3). Gonad needs apparently a determined DHA content which should be achieved during preconditioning period in the natural environment depending on this season at collection.

In contrast, an increase in EPA was only observed in gonads of oysters fed $T$. weissflogii when polar lipids were analyzed. When the neutral lipids were examined, however, EPA storage was found in all gonads except those of oysters fed $R$. salina. Such EPA accumulation during conditioning could be related to an insufficient initial 20:5(n-3) content (12\%: Fig. 2b), which differs from the final values (17\%: Fig. $3 b)$ in all diets tested in this previous study (González-Araya et al., 2010).

Fatty acid 20:4(n-6) was incorporated in both neutral and polar lipids of the gonad, but this incorporation was only noted in oysters fed $T$. pseudonana. This fatty acid is a major precursor of prostaglandins, which may influence the reproduction process in molluscs (Osada et al., 1989). Maturation was however more active in oysters fed $R$. salina and $T$. weissflogii.

Sterols are known to play a variety of roles in living organisms, acting as structural components of cell membranes, steroid hormones and vitamin D precursors (Soudant et al., 2000). In our study, the relative sterol composition of the organs was significantly influenced by diet. Thus, for oysters fed T. weissflogii and T. pseudonana, 24-Methylen-cholesterol, was 
efficiently transferred to the gonad. Similarly, brassicasterol was only accumulated in gonads of oysters fed $R$. salina.

In the present work, the sterols characteristic of $P$. lutheri (methylpavlovol and ethylpavlovol) did not show any accumulation in oyster gonads. Because the same trend was also observed in other tissues, we consider $P$. lutheri to be a poor microalgae species for $O$. edulis broodstock conditioning. This verdict is also based on the moderate physiological performances observed (moderate ingestion and absorption) and the poor gametogenesis development noted in oysters fed this species.

Despite the differing fatty acid and sterol composition of the diets, gametogenesis of $O$. edulis was globally successful, except when oysters were fed $P$. lutheri (as already mentioned) or not fed at all. This last point means that, although flat oyster tissue storage was clearly insufficient to support gametogenesis from an energetic point of view, initial stored reserves could have been crucial for essential requirements poorly covered by some of the diets. Our present study found the highest $O$. edulis reproductive performances in oysters fed $R$. salina, while our sister work recommended Chaetoceros gracilis or Skeletonema marinoi as the best from a comparison of four other species (González-Araya et al., 2010). T-Iso also showed some potential for $O$. edulis reproductive conditioning, although this was counterbalanced by low physiological performances with poor ingestion and absorption (González-Araya et al., 2010). R. salina offers similar biochemical characteristics as T-Iso but with higher physiological performances, which make it a better candidate. To balance diet and enhance flat oyster fecundity a mixed diet has been recommended (González-Araya et al., 2012). To improve reproductive performances a mixture based on C. gracilis (or S. marinoi) plus $R$. salina is highly recommended for $O$. edulis broodstock conditioning. The potential benefits of such microalgal assemblages for $O$. edulis broodstock fecundity and the quality of the larvae produced will be examined in a forthcoming paper.

\section{Conclusions}

Rhodomonas salina and Thalassiosira weissflogii are both as efficient feeds for Ostrea edulis conditioning.

1. Despite moderate physiological performances, Pavlova lutheri has no value for $O$. edulis conditioning due to low or inexistent transfer of dietary components.

2. The analysis of physiological and biochemical performances of flat oysters fed eight different microalgae species tested in separate experiments led us to recommend a mixed diet for $O$. edulis conditioning based on the association of Chaetoceros gracilis (or Skeletonema marinoi) plus R. salina.

\section{Acknowledgments}

This work could not have been completed without the technical support of the team at the Argenton Ifremer station - C. Mingant, I. Quéau, L. Lebrun and P. Le Souchu - all of whom 
we wish to thank. We are also grateful to the Universidad de Los Lagos (MECESUP-ULA 03/02), which contributed to the funding of a $\mathrm{PhD}$ grant for the first author. This work was carried out during the SETTLE project and was partially funded by FP7/2007-2013 under agreement $\mathrm{N}^{\circ} 222043$.

\section{References}

Barber, B.J., Blake, N.J., 1985. Intra-organ biochemical transformation associated with oogenesis in the bay scallop, Argopecten irradians concentricus (Say), as indicated by 14C incorporation. Biol. Bull. 168, 39-49.

Beiras, R., Camacho, A.P., Albentosa, M., 1994. Comparison of the scope for growth with the growth performance of Ostrea edulis seed reared at different food concentrations in an open system. Mar. Biol. 119 (2), 227-233.

Beninger, P.G., Decottignies, P., 2005. What makes diatoms attractive for suspensivores? The organic casing and associated organic molecules of Coscinodiscus perforatus are quality cues for the bivalve Pecten maximus. J. Plankton Res. 27(1), 11-17.

Ben Kheder, R., Quéré, C., Moal, J., Robert, R., 2010. Effect of nutrition on Crassostrea gigas larval development and the evolution of physiological indices. Part A: Quantitative and qualitative diet effects. Aquaculture 305, 165173.

Berntsson, K.M., Jonsson, P.R., Wängberg, S.Å., Carlsson, A.S., 1997. Effects of broodstock diets on fatty acid composition, survival and growth rates in larvae of the European flat oyster, Ostrea edulis. Aquaculture 154, 139-153.

Borowitzka, M. A., 1997. "Microalgae for aquaculture : opportunities and constraints." Journal of Applied Phycology 9(5): 393-401.

Caers, M., Coutteau, P., Sorgeloos P., 2000. Incorporation of different fatty acids, supplied as emulsions or liposomes, in the polar and neutral lipids of Crassostrea gigas spat. Aquaculture 186, 157-171.

Chavez-Villalba, J., Cochard, J.C., Le Pennec, M., Barret, J., Enriquez-Diaz, M., Caceres-Martinez, C., 2003. Effects of temperature and feeding regimes on gametogenesis and larval production in the oyster Crassostrea gigas. J. Shellfish Res, 22(3), 721-731.

Comps, M., 1970. Observation sur les causes d'une mortalité anormale des huîtres plates dans le bassin de Marennes. Rev. Travaux de l'ISTPM 34 (3), 317-326.

Comps, M., Tige, G., Grizel, H., 1980. Recherches ultrastructurales sur un protiste parasite de l'huître plate Ostrea edulis L. C.R.A.S., Sciences de la Vie 290 D, 383-384. 
Conover, R.J., 1966. Assimilation of organic matter zooplankton. Limnology and Oceanography 11, 338-345.

Delaporte, M., Soudant, P., Moal P., Giudicelli, E., Lambert, C.,Seguineau, C., Samain, J.F., 2006. Impact of 20:4n-6 supplementation on the fatty acid composition and hemocyte parameters of the Pacific Oyster Crassostrea gigas. Lipids 41, 567-576.

Dubois, M., Gilles, K.A., Hamilton, J.K., Rebers, P.A., Smith, F., 1956. Colorimetric method for determination of sugars and related substances. Analytical Chemistry 28, 350-356.

Eder, K., Reichlmayr-Lais, A.M, Kirchgessner, M., 1992. Simultaneous determination of amounts of major phospholipid classes and their fatty acid composition in erythrocyte membranes using high-performance liquid chromatography and gas chromatography. Journal of Chromatography $A$ 598,33-42.

Espinosa, E.P., Hassan, D., Ward, J.E., Shumway, S.E., Allam, B., 2010. Role of epicellular molecules in the selection of particles by the Blue mussel, Mytilus edulis. Bio Bul., 219 (1), 50-60.

Fabioux, C., Huvet, A., Le Souchu, P., Le Pennec, M., Pouvreau S., 2005. Temperature and photoperiod drive Crassostrea gigas reproductive internal clock. Aquaculture 250, 458-470.

Fearman, J., Moltschaniwskyj, N.A., 2010. Warmer temperatures reduce rates of gametogenesis in temperate mussels, Mytilus galloprovincialis. Aquaculture 305(1-4), 20-25.

Flores-Vergara, C., Cordero-Esquivel, B., Ceron-Ortiz, A.N., Arredondo-Vega, B.O., 2004. Combined effects of temperature and diet on growth and biochemical composition of the Pacific oyster Crassostrea gigas (Thunberg) spat. Aquaculture Research 35 (12), 1131-1140.

Folch, J.M., Lee, M, Sloane-Stanley, G.H., 1957. A simple method for the isolation and purification of total lipids from animal tissues. Journal of Biological Chemistry 266, 497-509.

Frolov, A.V., Pankov, S.L., 1992. The reproduction strategy of oyster Ostrea edulis L. from the biochemical point of view. Comp. Biochem. Physiol. 103B, 161-182.

Gabbott, P.A., Walker, A.J.M., 1971. Changes in the condition index and biochemical content of adult oysters (Ostrea edulis L.) maintained under hatchery conditions. Journal of Conservation and International Exploration 34, 99-106. 
Gallager, S.M., Mann, R., 1986. Growth and survival of larvae of Mercenaria mercenaria (L.) and Crassostrea virginica (Gmelin) relative to broodstock conditioning and lipid content of eggs. Aquaculture 56, 105-121.

González-Araya, R., Quéau, I., Quéré, C., Moal, J., Robert, R., 2010. A physiological and biochemical approach to selecting the ideal diet for Ostrea edulis (L.) broodstock conditioning: Part A. Aquacult. Res. 42, 1-17.

Gonzalez Araya, R., Petton, B., Mingant, C., Robert, R., 2012. Influence of diet assemblage on Ostrea edulis broodstock conditioning and subsequent larval development. Aquaculture, accepted.

Helm, M.M., 1990. Coltivazione di microalghe (Culture of microalgae). In: Allessandra G. (Ed). Tapes philippinarum. Biologia experimentazione, Ente Svillupo Agricolo Veneto, Venice, Italy, pp. 91-113.

Helm, M.M., Millican P.F., 1977. Experiments in hatchery rearing of Pacific oyster larvae (Crassostrea gigas Thunberg). Aquaculture 11(1), 1-12.

Helm, M., Holland, D.L., Stephenson, R.R., 1973. The effect of supplementary algal feeding of a hatchery breeding stock of Ostrea edulis L. on larval vigour. J. Mar. Biol. Assoc. U.K. 53, 673-684.

Helm, M.M., Holland, D.L., Utting, S. D., East, J., 1991. Fatty-acid composition of early non feeding larvae of the European flat oyster, Ostrea-edulis. J. Mar. Biol. Assoc. U.K. 71(3), 691-705.

Knauer, J., Southgate, P.C., 1999. A review of the nutritional requirements of bivalves and the development of alternative and artificial diets for bivalve aquaculture. Reviews in Fisheries Science 7, 241-280.

Laing, I., Walker, P., Areal, F., 2005. A feasibility study of native oyster (Ostrea edulis) stock regeneration in the United Kingdom. CARD Project FC1016, Native oyster Stock Regeneration - A review of Biological, Technical and Economic Feasibility, 95 pp.

Lallias, D., Boudry, P., Lapegue, S., King, J.W., Beaumont, A., 2010. Strategies for the retention of high genetic variability in European flat oyster (Ostrea edulis) restoration programmes. Conservation Genetics 11(5), 11891910.

Langdon, C.J., Waldock, M.J., 1981. The effect of algal and artificial diet on the growth and fatty acid composition of Crassostrea gigas spat. J. Mar. Biol. Assoc. U.K. 62, 431-448.

Le Pennec, M., Guéguen, F., Cochard, J.C., Paulet, Y.M., Dorange, G., 1991. Relations entre le contenu lipidique des ovocytes de Pecten maximus (Mollusque bivalve) et les performances de croissance en élevage. Haliotis, 20, 101-113. 
Lowry, O.H., Rosebrough, N.J., Farr, A.L., Randall, R.J., 1957. Protein measurement with the Folin phenol reagent. Journal of Biological Chemistry193, 265-275.

Mann, R., 1979. Some biological and physiological aspects of growth and gametogenesis in Crassostrea gigas and Ostrea edulis grown at sustained elevated temperatures. J. Mar. Biol. Assoc. UK 59, 95-110.

Martinez, G., Aguilera, C., Mettifogo L., 2000. Interactive effects of diet and temperature on reproductive conditioning of Argopecten purpuratus broodstock. Aquaculture 183(1-2), 149-159.

Martinez, G., Brokordt, K., Aguilera, C., Soto, V., Guderley, H., 2000. Effect of diet and temperature upon muscle metabolic capacities and biochemical composition of gonad and muscle in Argopecten purpuratus Lamarck 1819. J. Exp. Mar. Biol. Ecol. 247(1), 29-49.

Marty, Y., Delaunay, F., Moal, J., Samain, J.F., 1992. Changes in the fatty acid composition of Pecten maximus (L.) during larval development. Journal of Experimental Marine Biology and Ecology163, 221-234.

Millican, P.F., Helm M.M., 1994. Effects of nutrition on larvae production in the European flat oyster, Ostrea edulis. Aquaculture 123, 83-94.

Montes, J., Ferro-Soto, B., Conchas, R. F., Guerra, A., 2003. Determining culture strategies in populations of the European flat oyster, Ostrea edulis, affected by bonamiosis. Aquaculture 220(1-4), 175-182.

Naciri-Graven, Y., Martin, A.G., Baud, J.P., Renault, T, Gérard, A., 1988. Selecting the flat oyster Ostrea edulis (L.) for survival when infected with the parasite Bonamia ostreae. J. Exp. Mar. Biol. Ecol. 224, 91-107.

Osada, M., Nishikawa, M., Nomura, T., 1988. Involvement of prostaglandins in the spawning of the scallop, Patinopecten-yessoensis. Comparative Biochemistry and Physiology C-Pharmacology Toxicology \& Endocrinology 94 (2), 595-601.

Pernet, F., Barret, J., Marty, C., Moal, J., Le Gall, P., Boudry, P., 2010. Environmental anomalies, energetic reserves and fatty acid modifications in oysters coincide with an exceptional mortality event. MEPS 401, 129-146.

Pouvreau, S., Bourles, Y., Lefebvre, S., Gangnery, A., Alunno-Bruscia, M., 2006. Application of a dynamic energy budget model to the Pacific oyster, Crassostrea gigas, reared under various environmental conditions. J. Sea. Res. 56: 156-167.

Robert, R., Trintignac, P., 1996. Microalgues et nutrition larvaire en écloserie de mollusques. Haliotis, 26 : 1-13. 
Robert, R., His, E., Maurer, D., 1982. L'unité d'écophysiologie et de molysmologie larvaire des bivalves d'intérêt commercial du laboratoire d'Arcachon. Rev. Travaux de l'ISTPM 45 (3), 197-209.

Robert, R., Chrétiennot-Dinet, M.J., Kaas, R., Martin-Jézéquel, V., Moal, J., Le Coz, J.R., Nicolas, J.L., Bernard, E., Connan, J.P., Le Dean, L., Gourrierec, G., Leroy, B., Quéré, C., 2004. Amélioration des productions phytoplanctoniques en écloserie de mollusques: caractérisation des microalgues de fourrage, RI DRV/RA-2004-05, 149 pp.

Rico-Villa, B., Le Coz, J.R., Mingant, C., Robert, R., 2006. Influence of phytoplankton diet mixtures on microalgae consumption, larval development and settlement of the Pacific oyster Crassostrea gigas (Thunberg). Aquaculture 256 (1-4), 377-38.

Samain, J.F., Mc Combie, H., 2008. Summer mortality of Pacific oyster Crassostrea gigas. The Morest project, Edition Quae,Versailles, France,400 pp.

Savina, M., Pouvreau, S., 2004. A comparative ecophysiological study of two infaunal filter-feeding bivalves: paphia rhomboïdes and glycymeris glycymeris. Aquaculture 239, 289-306.

Soudant, P., Val Sanles, M., Quéré, C., Le Coz, J.R., Marty, Y., Moal J., Samain J.F., Sorgeloos, P., 2000. The use of lipid emulsions for sterol supplementation of spat of the Pacific oyster, Crassostrea gigas. Aquaculture184, 315-326.

Soudant, P., Le Coz, J.R., Marty, Y., Moal, J., Robert, R., Samain, J.F., 1998. Incorporation of microalgae sterols by scallop Pecten maximus (L.) larvae. Comp. Biochem.

Physiol. 119A, 451-457.

Soudant, P., Marty,Y., Moal, J., Robert, R., Quere, C., Le Coz, J.R., Samain, J.F., 1996. Effect of food fatty acid and sterol quality on Pecten maximus gonad composition and reproduction process. Aquaculture143, 361-378.

Saucedo, P.E., Racotta, I., Villareal, H., Monteforte, M., 2002. Seasonal changes in the histological and biochemical profile of the gonad, digestive gland and muscle of the Calafia mother-of-pearl oyster, Pinctada mazatlanica (Hanley 1856) associated with gametogenesis. J. Shellfish Res., 21, 127-135.

Thompson, P.A., Harrison, J.P., 1992. Effects of monospecific algal diets of varying biochemical composition on the growth and survival of Pacific oyster (Crassostrea gigas) larvae. Mar. Bio., 113, 645-654. 
Utting, S.D., Spencer, B.E., 1991. The hatchery culture of bivalve mollusc larvae and juveniles. Leaflet Laboratory of Ministry of Agriculture, Fisheries and Food, Directorate of Fisheries Research, Lowestoft, 68, 31 pp.

Volkman, J.K., Jeffrey, S.W., Nichols, P.D., Rogers, G.I., Garland, C.D., 1989. Fatty acid and lipid composition of 10 species of microalgae used in mariculture. J. Exp. Mar. Biol. Ecol., 128, 219-240.

Walne, P.R., 1966. Large scale culture of larvae of Ostrea edulis L. Fish. Invest., Series II, Volume XXV, Number 4, 52 pp.

Whyte, J.N.C., Bourne, N., Ginther, N.G., Hodgson, C.A., 1992. Compositional changes in the larva to juvenile development of the scallop Crassadoma gigantea (Gray). J. Exp. Mar. Biol. Ecol. 163, 13-29.

Yukihira, H., Klumpp, D.W., Lucas, J.S., 1998. Comparative effects of microalgal species and food concentration on suspension feeding and energy budgets of the pearl oysters Pinctada margaritifera and P-maxima (Bivalvia : Pteriidae). Mar. Ecol. Prog. 171, 71-84

\section{Web reference}

REPHY, 2011. Réseau de Surveillance du Phytoplancton et des phycotoxines. http://envlit.ifremer.fr.

\section{Figures}



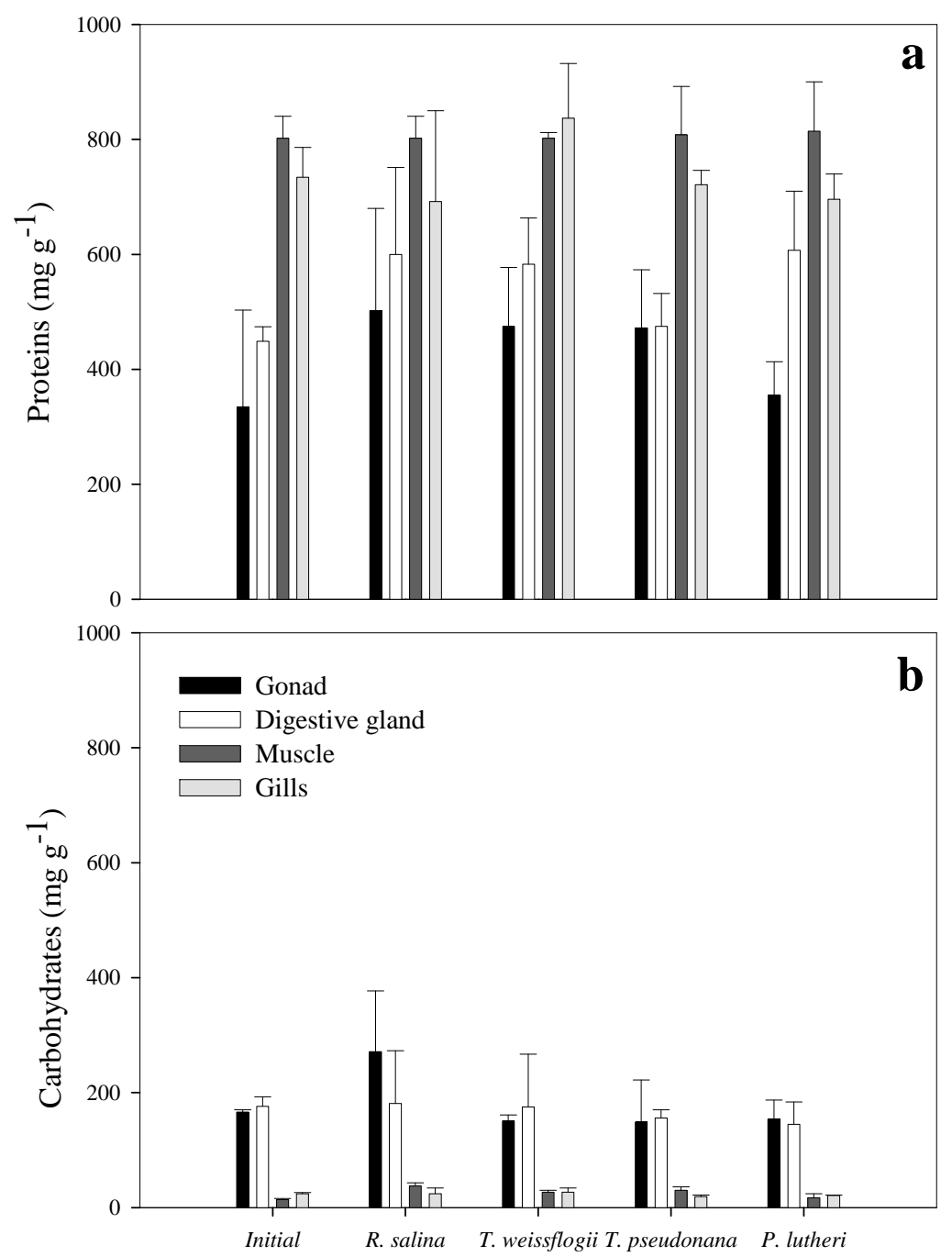

Fig. 1

Figure 1. Protein (a) and carbohydrate (b) contents of gonad, digestive gland, muscle and gills in European flat oyster Ostrea edulis (L.) broodstock, fed 4 microalgae species (values expressed in $\mathrm{dw} \mathrm{g}^{-1}$ tissue \pm S.D.; $\mathrm{n}=3$ ). 

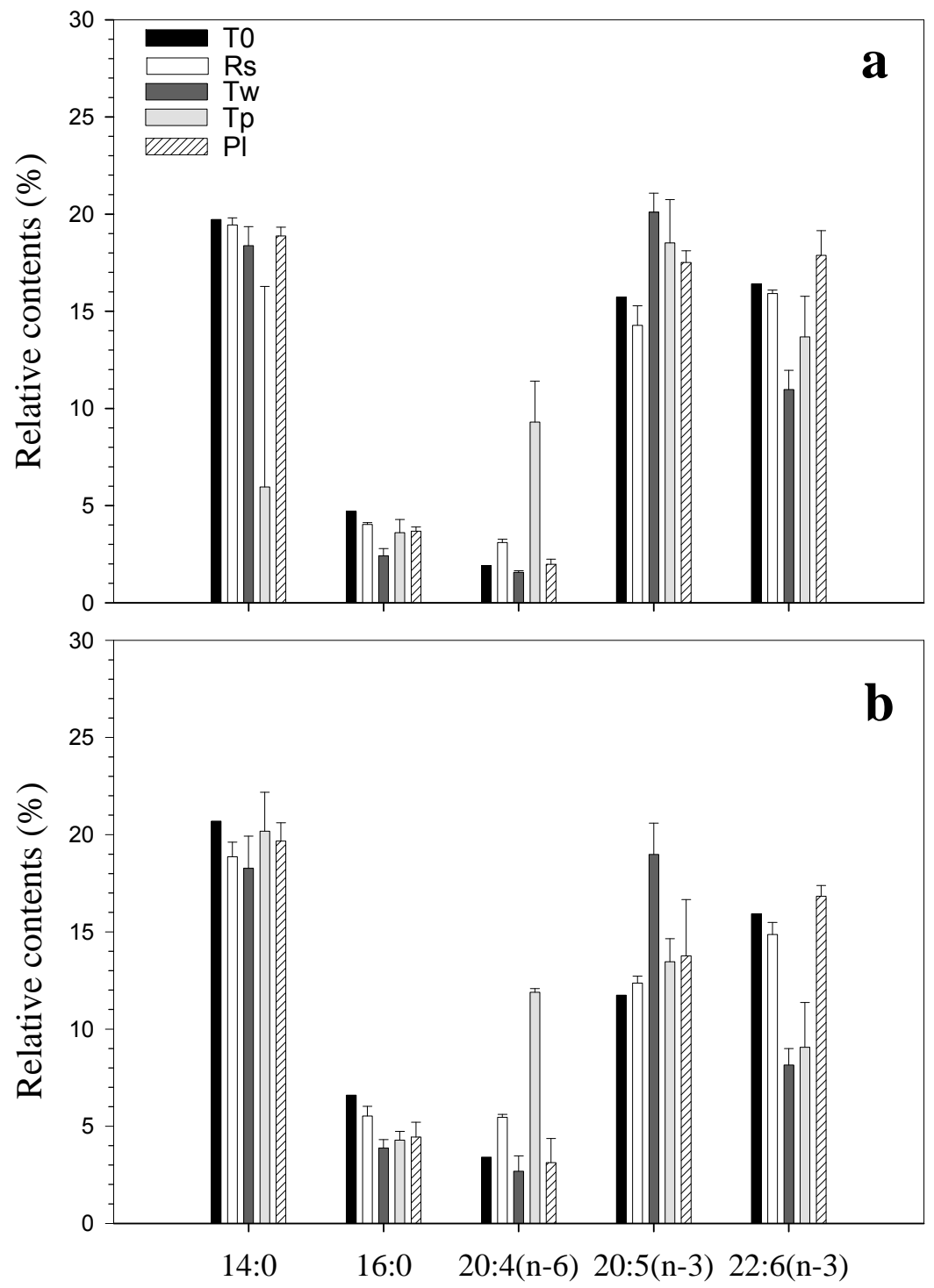

Fig. 2

Figure 2. Main fatty acid composition of neutral (a) and polar lipids (b) in gonad of Ostrea edulis broodstock according to diet: T0: Initial contents; Rs: Rhodomonas salina; Tw: Thalassiosira weissflogii; Tp: Thalassiosira pseudonana and PI: Pavlova lutheri, expressed in relative contents (mean weight $\%$ of fatty acids \pm S.D.). 

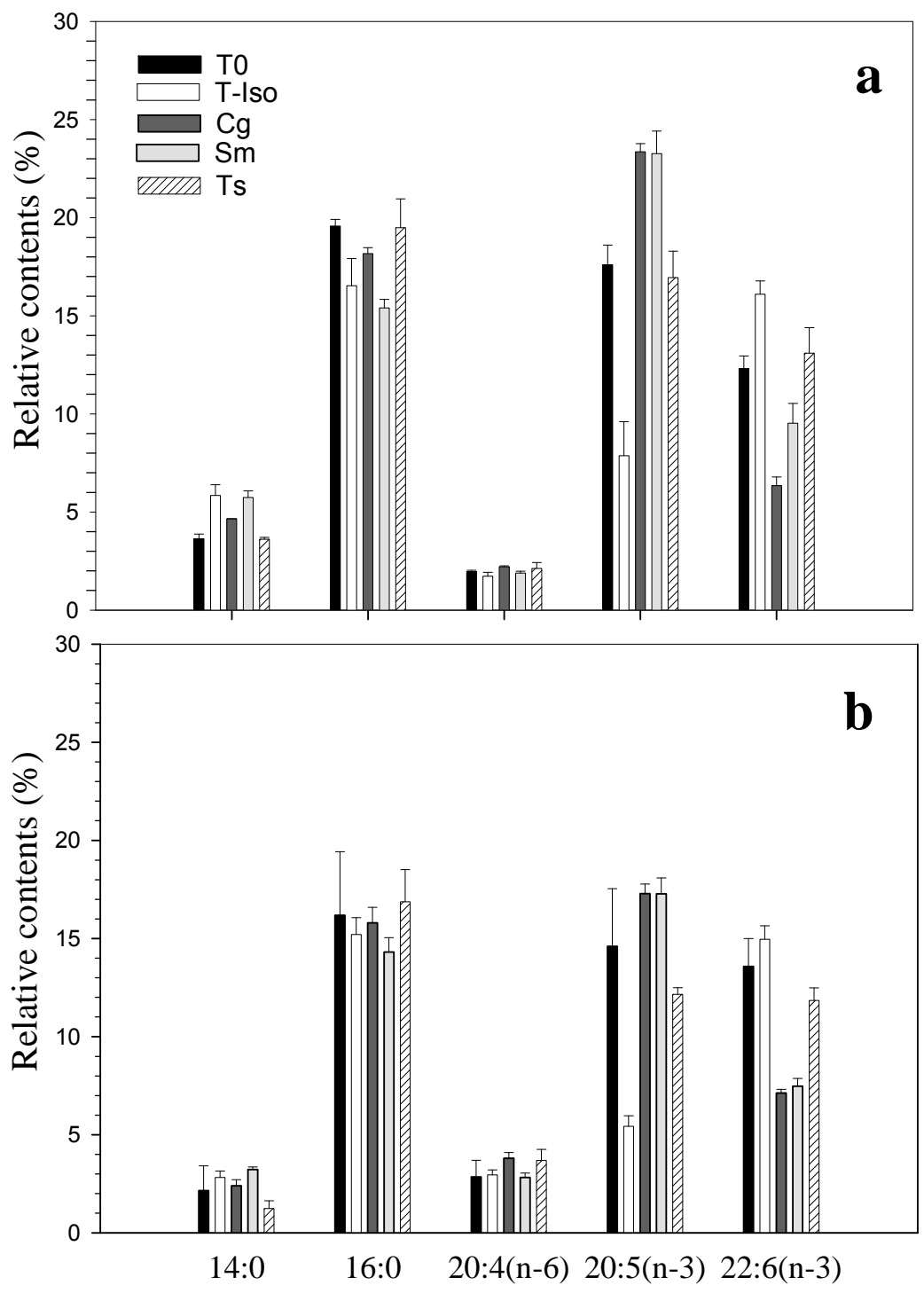

Fig. 3

Figure 3. Main fatty acid composition of neutral (a) and polar lipids (b) in gonad of Ostrea edulis broodstock according to diet: T0: Initial contents; T-Iso: Isochrysis affinis galbana; Cg: Chaetoceros gracilis; Sm: Skeletonema marino; Ts: Tetraselmis suecica, expressed in relative contents (mean weight $\%$ of fatty acids \pm S.D.).

\section{Tables}

Table 1. Fatty acid and sterol composition of total lipids of Rhodomonas salina, Thalassiosira weissflogii, Thalassiosira pseudonana and Pavlova lutheri expressed in mean relative content (weight $\%$ of total polar fatty acids \pm S.D., $n=3$ ).

Table 2. Fatty acid composition of the polar fraction in gonad of flat oysters fed monospecific diets (weight \% of total acids \pm S.D.).Values within the same line with a common 
superscript letter, in the corresponding column ( $x^{\prime}$ for absolute value, $x$ for relative value), are not significantly different at $p=0.05$.

Table 3. Fatty acid composition of the polar fraction in digestive gland of flat oysters fed mono-specific diets (weight \% of total acids \pm S.D.). Values within the same line with a common superscript letter, in the corresponding column ( $x$ ' for absolute value, $x$ for relative value), are not significantly different at $p=0.05$.

Table 4. Fatty acid composition of the polar fraction in muscle of flat oysters fed monospecific diets (weight \% of total acids \pm S.D.). Values within the same line with a common superscript letter, in the corresponding column ( $x$ ' for absolute value, $x$ for relative value), are not significantly different at $p=0.05$.

Table 5. Fatty acid composition of the polar fraction in gill of flat oysters fed monospecific diets (weight \% of total acids \pm S.D.). Values within the same line with a common superscript letter, in the corresponding column ( $x^{\prime}$ for absolute value, $x$ for relative value), are not significantly different at $p=0.05$.

Table 6. Main fatty acid composition of the polar fraction of the main tissues of unfed flat oysters (weight $\%$ of total acids \pm S.D.). ${ }^{*}$ indicate significant differences at $p=0.05$.

Table $7 \quad$ Sterol composition of different tissues of Ostrea edulis fed mono-specific diets (weight $\% \pm$ S.D.). Values within the same line with a common superscript letter are not significantly different at $p=0.05$.

Table 8 Gonad development (\%) in Ostrea edulis broodstock fed R. salina, T. weissflogii, T. pseudonana or $P$. lutheri for 6 -weeks. Stages: 0 , inactive; 1 , early active; 2, late active; 3 ripe; 4 , spent (see text for explanation: section Gonad development). 
Table 2

\begin{tabular}{|c|c|c|c|c|c|c|c|c|c|c|c|c|c|c|c|c|c|c|c|c|}
\hline \multirow{3}{*}{ Fatty acid } & & & & & \multicolumn{16}{|c|}{ Oyster diets } \\
\hline & \multicolumn{4}{|c|}{ Initial } & \multicolumn{4}{|c|}{ R. salina } & \multicolumn{4}{|c|}{ T. weissflogii } & \multicolumn{4}{|c|}{ T. pseudonana } & \multicolumn{4}{|c|}{ P. lutheri } \\
\hline & \multicolumn{2}{|c|}{$\begin{array}{l}\text { Contents } \\
\left(\mu \mathrm{g} \mathrm{mg}^{-1}\right)\end{array}$} & \multicolumn{2}{|c|}{$\begin{array}{c}\text { Rel. Contents } \\
(\%)\end{array}$} & \multicolumn{2}{|c|}{$\begin{array}{l}\text { Contents } \\
\left(\mu \mathrm{g} \mathrm{mg}^{-1}\right)\end{array}$} & \multicolumn{2}{|c|}{$\begin{array}{c}\text { Rel. Contents } \\
(\%)\end{array}$} & \multicolumn{2}{|c|}{$\begin{array}{l}\text { Contents } \\
\left(\mu \mathrm{g} \mathrm{mg}^{-1}\right)\end{array}$} & \multicolumn{2}{|c|}{$\begin{array}{c}\text { Rel. Contents } \\
(\%)\end{array}$} & \multicolumn{2}{|c|}{$\begin{array}{l}\text { Contents } \\
\left(\mu \mathrm{mg}^{-1}\right)\end{array}$} & \multicolumn{2}{|c|}{$\begin{array}{c}\text { Rel. Contents } \\
(\%)\end{array}$} & \multicolumn{2}{|c|}{$\begin{array}{l}\text { Contents } \\
\left(\mu g^{-1}\right)\end{array}$} & \multicolumn{2}{|c|}{$\begin{array}{c}\text { Rel. Contents } \\
(\%)\end{array}$} \\
\hline $14: 0$ & 0.16 & \pm 0.00 & 1.16 & \pm 0.88 & 0.24 & \pm 0.06 & 1.63 & \pm 0.16 & 0.30 & \pm 0.11 & 2.23 & \pm 0.36 & 0.33 & \pm 0.03 & 3.21 & \pm 1.39 & 1.13 & \pm 1.56 & 3.28 & \pm 1.59 \\
\hline $16: 0$ & 2.81 & \pm 0.00 & 20.70 & \pm 1.25 & 2.79 & \pm 0.65 & 18.86 & \pm 0.75 & 2.60 & \pm 1.20 & 18.27 & \pm 1.66 & 2.22 & \pm 0.54 & 20.18 & \pm 2.00 & 4.98 & \pm 5.33 & 19.68 & \pm 0.94 \\
\hline 18:0 & 0.89 & \pm 0.00 & 6.59 & \pm 0.45 & 0.80 & \pm 0.09 & 5.52 & \pm 0.50 & 0.53 & \pm 0.16 & 3.87 & \pm 0.44 & 0.49 & \pm 0.19 & 4.28 & \pm 0.45 & 1.00 & \pm 0.93 & 4.44 & \pm 0.76 \\
\hline $16: 1(n-7)$ & 0.32 & \pm 0.00 & 2.35 & \pm 1.13 & 0.14 & \pm 0.01 & 0.99 & \pm 0.11 & 0.98 & \pm 0.49 & 6.82 & \pm 0.69 & 0.56 & \pm 0.06 & 5.43 & \pm 2.35 & 1.16 & \pm 1.69 & 3.10 & \pm 2.02 \\
\hline $18: 1(n-9)$ & 0.31 & \pm 0.00 & 2.27 & \pm 1.25 & 0.21 & \pm 0.03 & 1.41 & \pm 0.12 & 0.24 & \pm 0.15 & 1.62 & \pm 0.48 & 0.15 & \pm 0.04 & 1.35 & \pm 0.07 & 0.74 & \pm 0.94 & 2.43 & \pm 0.65 \\
\hline $18: 1(n-7)$ & 0.23 & \pm 0.00 & 1.72 & \pm 1.69 & 0.15 & \pm 0.03 & 1.00 & \pm 0.02 & 0.58 & \pm 0.35 & 3.93 & \pm 0.77 & 0.38 & \pm 0.05 & 3.52 & \pm 0.82 & 0.95 & \pm 1.23 & 3.02 & \pm 0.99 \\
\hline $16: 3(n-3)$ & 0.37 & \pm 0.05 & 2.72 & \pm 1.06 & 0.40 & \pm 0.08 & 2.86 & \pm 1.02 & 0.38 & \pm 0.25 & 2.65 & \pm 1.73 & 0.27 & \pm 0.19 & 2.20 & \pm 1.13 & 0.41 & \pm 0.05 & 2.96 & \pm 1.90 \\
\hline $18: 2(n-6)$ & 0.17 & \pm 0.03 & 1.22 & \pm 0.29 & 0.95 & \pm 0.37 & 6.33 & \pm 1.27 & 0.13 & \pm 0.08 & 0.83 & \pm 0.25 & 0.15 & \pm 0.02 & 1.39 & \pm 0.40 & 0.46 & \pm 0.63 & 1.34 & \pm 0.63 \\
\hline $18: 4(n-3)$ & 0.16 & \pm 0.14 & 1.19 & \pm 0.45 & 0.27 & \pm 0.09 & 1.80 & \pm 0.30 & 0.08 & \pm 0.03 & 0.59 & \pm 0.05 & 0.18 & \pm 0.02 & 1.71 & \pm 0.49 & 0.48 & \pm 0.69 & 1.33 & \pm 0.78 \\
\hline $20: 2 i$ & 0.05 & \pm 0.03 & 0.33 & \pm 0.00 & 0.02 & \pm 0.00 & 0.12 & \pm 0.02 & 0.05 & \pm 0.02 & 0.37 & \pm 0.13 & 0.03 & \pm 0.01 & 0.26 & \pm 0.02 & 0.06 & \pm 0.03 & 0.33 & \pm 0.14 \\
\hline $20: 2 j$ & 0.03 & \pm 0.00 & 0.22 & \pm 0.01 & 0.01 & \pm 0.00 & 0.07 & \pm 0.02 & 0.04 & \pm 0.02 & 0.29 & \pm 0.03 & 0.03 & \pm 0.02 & 0.26 & \pm 0.13 & 0.04 & \pm 0.02 & 0.21 & \pm 0.09 \\
\hline $20: 2(n-6)$ & $a^{\prime} 0.03$ & \pm 0.02 & ${ }^{\mathrm{ab}} 0.22$ & \pm 0.01 & ${ }^{\text {b' }} 0.19$ & \pm 0.08 & $\mathrm{a}_{1.26}$ & \pm 0.27 & $a^{\prime} 0.02$ & \pm 0.01 & ${ }^{\mathrm{ab}} 0.13$ & \pm 0.06 & ${ }^{\prime}{ }^{\prime} 0.01$ & \pm 0.00 & ${ }^{b} 0.09$ & \pm 0.00 & $a^{\prime} b^{\prime} 0.07$ & \pm 0.08 & ${ }^{a b} 0.25$ & \pm 0.03 \\
\hline $20: 4(n-6)$ & ${ }^{a^{\prime}} 0.46$ & \pm 0.09 & 3.41 & \pm 1.01 & b' 0.80 & \pm 0.14 & 5.46 & \pm 0.15 & $\mathrm{a}^{\prime} 0.35$ & \pm 0.08 & 2.68 & \pm 0.80 & ${ }^{b^{\prime}} 1.33$ & \pm 0.41 & 11.89 & \pm 0.19 & $\mathrm{a}^{\prime} 0.58$ & \pm 0.37 & 3.13 & \pm 1.24 \\
\hline $20: 5(n-3)$ & 1.59 & \pm 0.97 & 11.74 & \pm 2.33 & 1.82 & \pm 0.41 & 12.36 & \pm 0.36 & 2.71 & \pm 1.32 & 18.98 & \pm 1.62 & 1.48 & \pm 0.36 & 13.46 & \pm 1.19 & 4.05 & \pm 5.00 & 13.77 & \pm 2.89 \\
\hline $22: 2 i$ & ${ }^{a} 0.17$ & \pm 0.02 & 1.22 & \pm 0.08 & ${ }^{\text {b' }} 0.10$ & \pm 0.00 & 0.67 & \pm 0.12 & 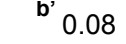 & \pm 0.02 & 0.56 & \pm 0.07 & ${ }^{b^{\prime}} 0.06$ & \pm 0.04 & 0.48 & \pm 0.26 & $\mathbf{a}^{\mathbf{a}^{\prime}} 0.13$ & \pm 0.02 & 0.92 & \pm 0.58 \\
\hline 22 :2j & 0.88 & \pm 0.31 & 6.52 & \pm 0.69 & 0.45 & \pm 0.02 & 3.15 & \pm 0.48 & 0.97 & \pm 0.38 & 6.94 & \pm 0.90 & 0.55 & \pm 0.34 & 4.52 & \pm 2.03 & 0.93 & \pm 0.34 & 5.86 & \pm 3.10 \\
\hline $22: 4(n-6)$ & 0.09 & \pm 0.06 & 0.69 & \pm 0.09 & 0.08 & \pm 0.07 & 0.58 & \pm 0.50 & 0.05 & \pm 0.01 & 0.40 & \pm 0.17 & 0.11 & \pm 0.08 & 0.93 & \pm 0.44 & 0.07 & \pm 0.02 & 0.44 & \pm 0.24 \\
\hline $22: 5(n-6)$ & 0.15 & \pm 0.04 & 1.10 & \pm 0.09 & ${ }^{a} 0.07$ & \pm 0.05 & 0.54 & \pm 0.41 & $a^{\prime} 0.05$ & \pm 0.02 & 0.38 & \pm 0.05 & ${ }^{a} 0.06$ & \pm 0.04 & 0.47 & \pm 0.19 & b' $^{\prime} 0.45$ & \pm 0.28 & 2.49 & \pm 1.06 \\
\hline $22: 5(n-3)$ & 0.16 & \pm 0.10 & 1.15 & \pm 0.11 & 0.16 & \pm 0.01 & 1.11 & \pm 0.17 & 0.16 & \pm 0.03 & 1.22 & \pm 0.29 & 0.09 & \pm 0.05 & 0.73 & \pm 0.23 & 0.18 & \pm 0.15 & 0.85 & \pm 0.22 \\
\hline $22: 6(n-3)$ & 2.16 & \pm 0.99 & 15.93 & \pm 2.89 & 2.18 & \pm 0.37 & 14.87 & \pm 0.62 & 1.15 & \pm 0.50 & 8.15 & \pm 0.85 & 1.07 & \pm 0.52 & 9.06 & \pm 2.30 & 4.27 & \pm 4.60 & 16.83 & \pm 0.56 \\
\hline TOMONO & 2.23 & \pm 0.57 & 16.45 & \pm 1.58 & 1.85 & \pm 0.34 & 12.58 & \pm 0.20 & 3.18 & \pm 1.51 & 22.25 & \pm 2.03 & 2.12 & \pm 0.55 & 19.19 & \pm 1.50 & 4.70 & \pm 5.61 & 16.62 & \pm 2.51 \\
\hline TO.(n-9) & 0.46 & \pm 0.02 & 3.37 & \pm 1.36 & 0.35 & \pm 0.12 & 2.40 & \pm 0.71 & 0.33 & \pm 0.13 & 2.39 & \pm 0.00 & 0.24 & \pm 0.03 & 2.23 & \pm 0.56 & 0.96 & \pm 1.22 & 3.17 & \pm 0.83 \\
\hline TO.(n-7) & 1.25 & \pm 0.09 & 9.23 & \pm 1.64 & 0.81 & \pm 0.12 & 5.54 & \pm 0.31 & 2.41 & \pm 1.16 & 16.85 & \pm 1.58 & 1.53 & \pm 0.32 & 14.00 & \pm 2.06 & 3.16 & \pm 3.87 & 10.85 & \pm 2.20 \\
\hline TO.POLY & 6.87 & \pm 1.36 & 50.69 & \pm 3.58 & 8.49 & \pm 1.64 & 57.72 & \pm 0.71 & 6.67 & \pm 2.84 & 47.29 & \pm 2.87 & 5.74 & \pm 2.13 & 50.34 & \pm 4.06 & 13.11 & \pm 13.55 & 53.56 & \pm 3.35 \\
\hline TO.(n-4) & 0.05 & \pm 0.00 & 0.37 & \pm 0.01 & 0.03 & \pm 0.01 & 0.18 & \pm 0.05 & 0.18 & \pm 0.12 & 1.23 & \pm 0.33 & 0.08 & \pm 0.00 & 0.72 & \pm 0.22 & 0.15 & \pm 0.21 & 0.45 & \pm 0.20 \\
\hline TO.(n-6) & 0.93 & \pm 0.09 & 6.87 & \pm 0.99 & 2.26 & \pm 0.55 & 15.27 & \pm 0.74 & 0.65 & \pm 0.20 & 4.83 & \pm 0.91 & 1.77 & \pm 0.54 & 15.77 & \pm 0.38 & 1.82 & \pm 1.64 & 8.20 & \pm 1.50 \\
\hline TO.(n-3) & 4.77 & \pm 1.25 & 35.14 & \pm 3.47 & 5.62 & \pm 1.06 & 38.25 & \pm 0.77 & 4.70 & \pm 2.11 & 33.04 & \pm 2.95 & 3.22 & \pm 1.17 & 28.29 & \pm 2.21 & 9.96 & \pm 11.24 & 37.54 & \pm 2.45 \\
\hline TO. NMI & 1.13 & \pm 0.08 & 8.30 & \pm 1.87 & 0.58 & \pm 0.03 & 4.01 & \pm 0.63 & 1.14 & \pm 0.44 & 8.16 & \pm 1.07 & 0.68 & \pm 0.41 & 5.52 & \pm 2.42 & 1.15 & \pm 0.41 & 7.32 & \pm 3.89 \\
\hline$(n-3) /(n-6)$ & $\mathbf{a}^{\prime} \mathbf{b}^{\prime} 5.11$ & \pm 2.33 & 5.11 & \pm 0.78 & ${ }^{a^{\prime}} 2.51$ & \pm 0.15 & 2.51 & \pm 0.15 & b' $_{7.05}$ & \pm 1.76 & 7.05 & \pm 1.76 & $\mathrm{a}^{\mathbf{a}^{\prime}} 1.80$ & \pm 0.18 & 1.80 & \pm 0.18 & $\mathbf{a}^{\prime} \mathbf{b}^{\prime} 4.73$ & \pm 1.26 & 4.73 & \pm 1.26 \\
\hline $22: 6 / 20: 5$ & 1.36 & \pm 0.78 & 1.36 & \pm 0.01 & 1.20 & \pm 0.08 & 1.20 & \pm 0.08 & 0.43 & \pm 0.05 & 0.43 & \pm 0.05 & 0.68 & \pm 0.21 & 0.68 & \pm 0.21 &, 1.26 & \pm 0.24 & 1.26 & \pm 0.24 \\
\hline $22: 5 / 20: 4$ & ${ }^{a^{\prime}} 0.32$ & \pm 0.05 & 0.32 & \pm 0.08 & ${ }^{b^{\prime}} 0.10$ & \pm 0.07 & 0.10 & \pm 0.07 & ${ }^{a^{\prime} b^{\prime}} 0.15$ & \pm 0.02 & 0.15 & \pm 0.02 & 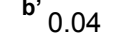 & \pm 0.02 & 0.04 & \pm 0.02 & $\mathrm{c}^{\prime} 0.80$ & \pm 0.16 & 0.80 & \pm 0.16 \\
\hline TOTAL & 13.56 & \pm 8.49 & 100.00 & \pm 0.00 & 14.71 & \pm 2.92 & 100.00 & \pm 0.00 & 13.99 & \pm 5.61 & 100.00 & \pm 0.00 & 11.23 & \pm 3.52 & 100.00 & \pm 0.00 & 25.53 & \pm 27.63 & 100.00 & \pm 0.00 \\
\hline
\end{tabular}


Table 3

\begin{tabular}{|c|c|c|c|c|c|c|c|c|c|c|c|c|c|c|c|c|c|c|c|c|}
\hline \multirow{3}{*}{ Fatty acid } & & & & & \multicolumn{16}{|c|}{ Oyster diets } \\
\hline & \multicolumn{4}{|c|}{ Initial } & \multicolumn{4}{|c|}{ R. salina } & \multicolumn{4}{|c|}{ T. weissflogii } & \multicolumn{4}{|c|}{ T. pseudonana } & \multicolumn{4}{|c|}{ P. lutheri } \\
\hline & \multicolumn{2}{|c|}{$\begin{array}{l}\text { Contents } \\
\left(\mu \mathrm{g} \mathrm{mg}^{-1}\right)\end{array}$} & \multicolumn{2}{|c|}{$\begin{array}{l}\text { Rel. Contents } \\
(\%)\end{array}$} & \multicolumn{2}{|c|}{$\begin{array}{l}\text { Contents } \\
\left(\mu g \mathrm{mg}^{-1}\right)\end{array}$} & \multicolumn{2}{|c|}{$\begin{array}{l}\text { Rel. Contents } \\
(\%)\end{array}$} & \multicolumn{2}{|c|}{$\begin{array}{l}\text { Contents } \\
\left(\mu \mathrm{mg}^{-1}\right)\end{array}$} & \multicolumn{2}{|c|}{$\begin{array}{c}\text { Rel. Contents } \\
(\%)\end{array}$} & \multicolumn{2}{|c|}{$\begin{array}{l}\text { Contents } \\
\left(\mu g \mathrm{mg}^{-1}\right)\end{array}$} & \multicolumn{2}{|c|}{$\begin{array}{c}\text { Rel. Contents } \\
(\%)\end{array}$} & \multicolumn{2}{|c|}{$\begin{array}{l}\text { Contents } \\
\left(\mu \mathrm{g} \mathrm{mg}^{-1}\right) \\
\end{array}$} & \multicolumn{2}{|c|}{$\begin{array}{c}\text { Rel. Contents } \\
(\%)\end{array}$} \\
\hline 14:0 & 0.20 & \pm 0.03 & 1.37 & \pm 0.16 & 0.22 & \pm 0.11 & 1.06 & \pm 0.16 & 0.23 & \pm 0.04 & 1.39 & \pm 0.15 & 0.20 & \pm 0.02 & 1.64 & \pm 0.05 & 0.25 & \pm 0.05 & 1.61 & \pm 0.24 \\
\hline 16:0 & 2.70 & \pm 0.13 & 18.12 & \pm 0.61 & 3.53 & \pm 1.26 & 17.50 & & & \pm 0.12 & & & 2.27 & \pm 0.18 & 18.17 & & 3.07 & & 19.53 & \\
\hline 18:0 & 1.01 & \pm 0.06 & 6.75 & \pm 0.23 & 1.49 & \pm 0.55 & 7.37 & \pm 0.25 & 0.85 & \pm 0.03 & 5.24 & \pm 0.14 & 0.73 & \pm 0.04 & 5.84 & \pm 0.20 & 0.87 & \pm 0.19 & 5.50 & \pm 0.27 \\
\hline $16: 1(n-7)$ & 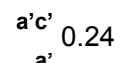 & \pm 0.02 & b 1.64 & \pm 0.08 & $a^{a} 0.11$ & \pm 0.05 & ${ }^{\mathrm{a}} 0.54$ & \pm 0.08 & b' 0.67 & \pm 0.11 & b 4.12 & \pm 0.47 & $c^{\prime} 0.33$ & \pm 0.03 & ${ }^{a b} 2.66$ & \pm 0.12 & $a^{a} c^{\prime} 0.22$ & \pm 0.04 & ab 1.41 & \pm 0.08 \\
\hline $18: 1(n-9)$ & $a^{\prime} 0.32$ & \pm 0.01 & 2.16 & \pm 0.04 & $a^{\prime} b^{\prime} 0.22$ & \pm 0.08 & 1.06 & \pm 0.06 & 'l'b' 0.24 & \pm 0.02 & 1.50 & \pm 0.03 & ${ }^{\text {b' }} 0.15$ & \pm 0.02 & 1.22 & \pm 0.04 & $\mathrm{a}^{\prime} 0.28$ & \pm 0.05 & 1.79 & \pm 0.01 \\
\hline $18: 1(n-$ & $a^{\prime} 0.24$ & \pm 0.01 & ab 1.63 & \pm 0.02 & 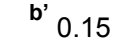 & \pm 0.06 & b 0.72 & \pm 0.04 & ${ }^{c} 0.53$ & \pm 0.07 & ${ }^{a} 3.28$ & \pm 0.25 & ${ }^{d \prime} 0.33$ & \pm 0.04 & ${ }^{\mathrm{a}} 2.62$ & \pm 0.09 & $\mathrm{e}^{\prime} 0.00$ & \pm 0.00 & ${ }^{c} 0.00$ & \pm 0.00 \\
\hline $16: 3(r$ & 0.37 & \pm 0.02 & 2.50 & & 0.77 & & 3.75 & & 0.53 & & & & 0.35 & & 2.80 & & 0.51 & & 3.24 & \\
\hline $18: 2(n-6)$ & $\mathrm{a}^{\prime} 0.15$ & \pm 0.01 & $a_{1.03}$ & \pm 0.03 & b' 0.91 & \pm 0.32 & ${ }^{b} 4.49$ & \pm 0.08 & ${ }^{a} 0.09$ & \pm 0.02 & ${ }^{a} 0.58$ & \pm 0.07 & ${ }^{a} 0.10$ & \pm 0.01 & ${ }^{\mathrm{a}} 0.82$ & \pm 0.09 & ${ }^{a} 0.14$ & \pm 0.02 & ${ }^{\mathrm{a}} 0.91$ & \pm 0.06 \\
\hline $18: 4(n-3)$ & $a^{\prime}, 0.13$ & \pm 0.02 & 0.85 & \pm 0.13 & ${ }^{\text {b' }} 0.27$ & \pm 0.09 & 1.35 & \pm 0.05 & $a^{a^{\prime}} 0.08$ & \pm 0.01 & 0.50 & \pm 0.11 & ${ }^{a^{\prime}}, 0.14$ & \pm 0.01 & 1.09 & \pm 0.04 & $a^{\prime}, 0.11$ & \pm 0.02 & 0.68 & \pm 0.06 \\
\hline $20: 2 i$ & 0.08 & \pm 0.01 & 0.51 & \pm 0.03 & b' 0.03 & \pm 0.01 & 0.16 & \pm 0.01 & 0.08 & \pm 0.01 & 0.51 & \pm 0.08 & ${ }^{\text {b' }} 0.04$ & \pm 0.00 & 0.32 & \pm 0.02 & ${ }^{a} 0.08$ & \pm 0.02 & 0.52 & \pm 0.06 \\
\hline 20 :2j & $\mathrm{a}^{\prime} 0.04$ & \pm 0.00 & 0.26 & \pm 0.01 & $\mathrm{~b}^{\prime} 0.01$ & \pm 0.00 & 0.07 & \pm 0.01 & $\mathrm{a}^{\prime} 0.06$ & \pm 0.01 & 0.35 & \pm 0.07 & $\mathrm{a}^{\prime} 0.05$ & \pm 0.01 & 0.38 & \pm 0.03 & $\mathrm{a}^{\prime} 0.05$ & \pm 0.01 & 0.30 & \pm 0.02 \\
\hline $20: 2(n-6)$ & ${ }^{a^{\prime}} 0.03$ & \pm 0.00 & ${ }^{a} 0.21$ & \pm 0.00 & b' 0.23 & \pm 0.06 & b 1.17 & \pm 0.11 & ${ }^{\prime}, 0.03$ & \pm 0.01 & ${ }^{\mathrm{a}} 0.18$ & \pm 0.05 & ${ }^{a}, 0.01$ & \pm 0.00 & ${ }^{a} 0.09$ & & $a^{\prime} 0.04$ & \pm 0.01 & ${ }^{a} 0.2$ & \pm 0.00 \\
\hline $20: 4(n-6$ & $\mathbf{a}^{\prime} \mathbf{b}^{\prime} 0.72$ & \pm 0.01 & ${ }^{b} 4.86$ & \pm 0.11 & $a^{\prime} c^{\prime} 1.33$ & \pm 0.50 & ${ }^{\mathrm{ab}} 6.58$ & \pm 0.26 & ${ }^{\text {b' }} 0.44$ & \pm 0.03 & b 2.73 & \pm 0.10 & $c^{\prime} 1.64$ & \pm 0.20 & ${ }^{a} 13.07$ & & $a^{\prime} b^{\prime} 0.77$ & & ${ }^{b} 4$. & \\
\hline $20: 5(n-3)$ & $\mathbf{a}^{\prime} \mathbf{b}^{\prime} 1.71$ & \pm 0.08 & 11.45 & \pm 0.36 & $\mathbf{a}^{\prime} \mathbf{b}^{\prime} 2.37$ & \pm 0.82 & 11.76 & \pm 0.04 & ${ }^{a^{\prime}} 2.86$ & \pm 0.32 & 17.59 & \pm 0.92 & b' $_{1.30}$ & \pm 0.16 & 10.36 & \pm 0.47 & $a^{\prime} b^{\prime} 1.74$ & .39 & 11.04 & \pm 0.51 \\
\hline $22: 2 i$ & ${ }^{a^{\prime}} 0.19$ & \pm 0.00 & $a_{1.27}$ & \pm 0.00 & $\mathbf{b}^{\prime} 0.13$ & \pm 0.04 & ${ }^{a b} 0.64$ & \pm 0.03 & ${ }^{\prime} 0.08$ & \pm 0.00 & ${ }^{\mathrm{b}} 0.47$ & \pm 0.02 & ${ }^{\prime}{ }^{\prime} 0.07$ & \pm 0.00 & ${ }^{a b} 0.56$ & \pm 0.02 & $\mathrm{a}^{\mathrm{a}} 0.17$ & \pm 0.04 & ab 1.09 & \pm 0.03 \\
\hline 22 :2j & $a^{a^{\prime} b^{\prime}}, 1.18$ & \pm 0.02 & 7.93 & \pm 0.18 & $a^{\prime}, 0.75$ & \pm 0.27 & 3.69 & \pm 0.15 & 1.63 & \pm 0.02 & 10.12 & \pm 0.73 & ${ }^{a^{\prime}} 0.99$ & \pm 0.11 & 7.94 & \pm 0.33 & , 1.63 & \pm 0.36 & 10.33 & \pm 0.21 \\
\hline $22: 4(n-6)$ & $\mathbf{a}^{\prime} \mathbf{b}^{\prime} 0.10$ & \pm 0.01 & 0.66 & \pm 0.05 & ${ }^{a^{\prime}} 0.13$ & \pm 0.05 & 0.64 & \pm 0.03 & ${ }^{\text {b' }} 0.04$ & \pm 0.00 & 0.24 & \pm 0.03 & ${ }^{a} 0.14$ & \pm 0.02 & 1.14 & \pm 0.11 & 'b' 0.08 & \pm 0.02 & 0.48 & \pm 0.01 \\
\hline $22: 5(n-6)$ & ${ }^{a^{\prime}} 0.21$ & \pm 0.00 & ab 1.43 & \pm 0.06 & $\mathbf{a}^{\prime} \mathbf{b}^{\prime} 0.14$ & \pm 0.06 & ${ }^{a} 0.71$ & \pm 0.02 & 0.05 & \pm 0.00 & ${ }^{\mathrm{a}} 0.33$ & \pm 0.01 & ${ }^{\text {b' }} 0.08$ & \pm 0.01 & ${ }^{\mathrm{a}} 0.62$ & \pm 0.05 & 0.60 & \pm 0.07 & b 3.87 & \pm 0.29 \\
\hline $22: 5(n-$ & $\mathbf{a}^{\prime} \mathbf{b}^{\prime} 0.17$ & \pm 0.00 & 1.12 & \pm 0.04 & ${ }^{a}, 0.21$ & \pm 0.08 & 1.01 & \pm 0.03 & $a^{a} b^{\prime} 0.16$ & \pm 0.01 & 0.98 & \pm 0.0 & ${ }^{\mathbf{b}^{\prime}} 0.10$ & \pm 0.01 & 0.81 & \pm 0 & $a^{\prime} b^{\prime} 0.11$ & \pm 0.02 & 0.70 & \pm 0.06 \\
\hline $22: 6(n-3)$ & ${ }^{a^{\prime} b^{\prime}} 2.40$ & \pm 0.06 & 16.07 & \pm 0.46 & ${ }^{\text {b' }} 3.17$ & \pm 1.07 & 15.75 & \pm 0.15 & 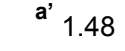 & \pm 0.14 & 9.13 & \pm 0.35 & $a^{\prime} 1.30$ & \pm 0.09 & 10.40 & \pm 0.25 & a'b' 2.45 & \pm 0.44 & 15.60 & \pm 0.74 \\
\hline TO.MONO & 2.43 & & 16.32 & & 2.29 & & 11.31 & & & & & & 2.0 & & 16.58 & & & & 13.04 & \\
\hline TO.(n-9) & $a^{\prime} c^{\prime} 0.51$ & \pm 0.03 & 3.41 & \pm 0.20 & $a^{\prime} c^{\prime} 0.55$ & \pm 0.20 & 2.72 & & $a^{\prime} 0.6$ & & 4.23 & & ${ }^{b^{\prime}} 0.21$ & & 1.69 & & ${ }^{\rho^{\prime} \mathbf{c}} 0.36$ & \pm 0.06 & 2.30 & \pm 0.13 \\
\hline TO.(n-7) & $\mathrm{a}^{\prime} 1.29$ & \pm 0.04 & 8.64 & \pm 0.12 & ${ }^{a} 0.94$ & \pm 0.37 & 4.64 & \pm 0.22 & b' 2.19 & & 13.47 & & $\mathrm{a}^{\prime} 1.42$ & & 11.34 & \pm 0.15 & $a^{\prime} 1.08$ & \pm 0.21 & 6.88 & \pm 0.23 \\
\hline & 7.90 & \pm 0.20 & 52.95 & & 11.74 & \pm 4.09 & 58.25 & & 8.03 & & & & 6.58 & & 52.66 & & 9.04 & & 57. & \\
\hline TO.(n-4) & ${ }^{a}, 0.06$ & \pm 0.01 & ${ }^{\mathrm{ab}} 0.40$ & \pm 0.03 & ${ }^{\prime}, 0.03$ & \pm 0.01 & ${ }^{a} 0.12$ & \pm 0.02 & ${ }^{\text {b' }} 0.15$ & \pm 0.02 & ${ }^{b} 0.92$ & \pm 0.05 & ${ }^{\prime}, 0.06$ & \pm 0.01 & ${ }^{\mathrm{ab}} 0.46$ & \pm 0.02 & ${ }^{a}, 0.04$ & \pm 0.01 & ${ }^{\mathrm{ab}} 0.27$ & \pm 0.02 \\
\hline TO.(n-6) & ${ }^{a} 1.27$ & \pm 0.02 & ab 8.50 & \pm 0.13 & b' 2.91 & \pm 1.02 & $a_{14.43}$ & \pm 0.24 & ${ }^{a^{\prime}} 0.69$ & \pm 0.06 & b 4.27 & \pm 0.09 & a'b' 2.05 & \pm 0.24 & ${ }^{a} 16.41$ & \pm 0.65 & $a^{\prime} b^{\prime} 1.69$ & \pm 0.30 & ab 10.75 & \pm 0.20 \\
\hline TO.(n-3) & $\mathbf{a}^{\prime} \mathbf{b}^{\prime} 5.07$ & \pm 0.16 & 34.01 & \pm 0.84 & $a^{\prime} 7.88$ & \pm 2.72 & 39.12 & \pm 0.32 & $\mathbf{a}^{\prime} \mathbf{b}^{\prime} 5.33$ & \pm 0.27 & 32.90 & \pm 0.39 & 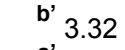 & \pm 0.32 & 26.58 & \pm 0.59 & $a^{\prime} b^{\prime} 5.38$ & \pm 1.04 & 34.23 & \pm 1.40 \\
\hline TO. NMI & $\begin{array}{l}\mathbf{a}^{\prime} \mathbf{b}^{\prime} \\
1.49\end{array}$ & \pm 0.03 & 9.97 & \pm 0.19 & $\mathrm{a}^{\prime} 0.92$ & \pm 0.33 & 4.56 & \pm 0.18 & b' $_{1.85}$ & \pm 0.02 & 11.45 & \pm 0.74 & $\mathrm{a}^{\prime} 1.15$ & \pm 0.12 & 9.20 & \pm 0.33 & $\mathbf{b}^{\prime} 1.93$ & \pm 0.42 & 12.24 & \pm 0.23 \\
\hline$(n-3) /(n-6)$ & & \pm 0.13 & ab 4.00 & \pm 0.13 & b' 2.71 & \pm 0.02 & ${ }^{\mathrm{a}} 2.71$ & \pm 0.02 & & \pm 0.25 & b 7.71 & \pm 0.25 & $\mathrm{~d}^{\prime} 1.62$ & \pm 0.04 & aa 1.62 & \pm 0.04 & $\mathbf{e}^{\prime} 3.18$ & \pm 0.11 & a 3.18 & \pm 0.11 \\
\hline $22: 6 / 20: 5$ & $a^{\prime} 1.40$ & \pm 0.03 & 1.40 & \pm 0.03 & $\mathbf{a}^{\prime} 1.34$ & \pm 0.02 & 1.34 & \pm 0.02 & ${ }^{\text {b' }} 0.52$ & \pm 0.02 & 0.52 & \pm 0.02 & ${ }^{\prime}{ }_{1.01}$ & \pm 0.07 & 1.01 & \pm 0.07 & $\mathbf{a}^{\prime} 1.41$ & \pm 0.06 & 1.41 & \pm 0.06 \\
\hline $22: 5 / 20: 4$ & ${ }^{a} 0.29$ & \pm 0.01 & ${ }^{\mathrm{ab}} 0.29$ & \pm 0.01 & ${ }^{\text {b' }} 0.11$ & \pm 0.00 & ${ }^{b} 0.11$ & \pm 0.00 & $\mathbf{b}^{\prime} 0.12$ & \pm 0.00 & ${ }^{\mathrm{b}} 0.12$ & \pm 0.00 & 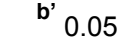 & \pm 0.00 & ${ }^{b} 0.05$ & \pm 0.00 & ${ }^{c^{\prime}} 0.80$ & \pm 0.08 & ${ }^{\mathrm{a}} 0.80$ & \pm 0.08 \\
\hline TOTAL & 14.91 & \pm 0.40 & 100.00 & \pm 0.00 & 20.15 & \pm 6.95 & 100.00 & \pm 0.00 & 16.20 & \pm 1.00 & 100.00 & \pm 0.00 & 12.48 & \pm 1.07 & 100.00 & \pm 0.00 & 15.73 & \pm 3.10 & 100.00 & \pm 0.00 \\
\hline
\end{tabular}




\begin{tabular}{|c|c|c|c|c|c|c|c|c|c|c|c|c|c|c|c|c|c|c|c|c|}
\hline \multirow{3}{*}{ Fatty acid } & & & & & \multicolumn{16}{|c|}{ Oyster diets } \\
\hline & \multicolumn{4}{|c|}{ Initial } & \multicolumn{4}{|c|}{ R. salina } & \multicolumn{4}{|c|}{ T. weissflogii } & \multicolumn{4}{|c|}{ T.pseudonana } & \multicolumn{4}{|c|}{ P. lutheri } \\
\hline & \multicolumn{2}{|c|}{$\begin{array}{l}\text { Contents } \\
\left(\mu \mathrm{mg}^{-1}\right) \\
\end{array}$} & \multicolumn{2}{|c|}{$\begin{array}{c}\text { Rel. Contents } \\
(\%)\end{array}$} & \multicolumn{2}{|c|}{$\begin{array}{l}\text { Contents } \\
\left(\mu \mathrm{mg}^{-1}\right)\end{array}$} & \multicolumn{2}{|c|}{$\begin{array}{c}\text { Rel. Contents } \\
(\%)\end{array}$} & \multicolumn{2}{|c|}{$\begin{array}{l}\text { Contents } \\
\left(\mu \mathrm{g} \mathrm{mg}^{-1}\right)\end{array}$} & \multicolumn{2}{|c|}{$\begin{array}{c}\text { Rel. Contents } \\
(\%)\end{array}$} & \multicolumn{2}{|c|}{$\begin{array}{l}\text { Contents } \\
\left(\mu \mathrm{mg}^{-1}\right)\end{array}$} & \multicolumn{2}{|c|}{$\begin{array}{c}\text { Rel. Contents } \\
(\%)\end{array}$} & \multicolumn{2}{|c|}{$\begin{array}{l}\text { Contents } \\
\left(\mu \mathrm{g} \mathrm{m}^{-1}\right) \\
\end{array}$} & \multicolumn{2}{|c|}{$\begin{array}{c}\text { Rel. Contents } \\
(\%)\end{array}$} \\
\hline $14: 0$ & $\mathbf{a}^{\prime} \mathbf{b}^{\prime} 0.08$ & \pm 0.01 & 1.02 & \pm 0.04 & 0.07 & \pm 0.01 & 0.70 & \pm 0.07 & 0.11 & \pm 0.02 & 1.14 & \pm 0.18 & 0.12 & \pm 0.02 & 1.21 & \pm 0.11 & 0.08 & \pm 0.02 & 0.94 & \pm 0.13 \\
\hline 16:0 & $\mathrm{a}_{1.36}$ & \pm 0.05 & 16.30 & \pm 0.11 & b'0.89 & \pm 0.01 & 9.45 & \pm 0.23 & b' 0.96 & \pm 0.04 & 10.04 & \pm 0.25 & ${ }^{\text {b' }} 0.99$ & \pm 0.14 & 10.32 & \pm 0.56 & 0.84 & \pm 0.12 & 9.89 & \pm 0.60 \\
\hline 18:0 & 0.52 & \pm 0.00 & 6.22 & \pm 0.24 & 0.56 & \pm 0.02 & 5.96 & \pm 0.19 & 0.52 & \pm 0.06 & 5.43 & \pm 0.54 & 0.58 & \pm 0.08 & 5.99 & \pm 0.45 & 0.52 & \pm 0.06 & 6.22 & \pm 1.31 \\
\hline $16: 1(n-7)$ & ${ }^{a} 0.07$ & \pm 0.01 & 0.89 & \pm 0.10 & ${ }^{a^{\prime}} 0.07$ & \pm 0.01 & 0.71 & \pm 0.13 & $\mathbf{b}^{\prime} 0.28$ & \pm 0.03 & 2.89 & \pm 0.28 & $\mathrm{c}^{\prime} 0.17$ & \pm 0.01 & 1.76 & \pm 0.08 & $\mathrm{a}^{\prime} 0.08$ & \pm 0.02 & 0.97 & \pm 0.13 \\
\hline $18: 1(r$ & 0.14 & \pm 0.01 & 1.64 & \pm 0.10 & 0.12 & \pm 0.01 & 1.29 & \pm 0.10 & 0.13 & \pm 0.02 & 1.35 & \pm 0.22 & 0.12 & \pm 0.00 & 1.24 & \pm 0.06 & 0.12 & \pm 0.01 & 1.39 & \pm 0.03 \\
\hline $18: 1(n-7)$ & $a^{\prime} b^{\prime} 0.09$ & \pm 0.01 & 1.10 & \pm 0.06 & ${ }^{b^{\prime}} 0.06$ & \pm 0.01 & 0.68 & \pm 0.12 & ${ }^{\prime} \quad 0.21$ & \pm 0.01 & ${ }^{\mathrm{c}} 2.16$ & \pm 0.13 & ${ }^{\prime}{ }_{0.17}^{\prime}$ & \pm 0.03 & 1.80 & \pm 0.13 & $\mathbf{a}^{\prime} \mathbf{b}^{\prime}{ }^{\prime} 0.10$ & \pm 0.02 & 1.22 & \pm 0.18 \\
\hline $16: 3(n-3)$ & $\mathrm{a}^{\prime} 0.25$ & \pm 0.13 & 3.03 & \pm 1.40 & b' 0.05 & \pm 0.02 & 0.55 & \pm 0.25 & $\mathrm{a}^{\prime} 0.08$ & \pm 0.02 & 0.87 & \pm 0.19 & $\mathrm{a}^{\mathrm{\prime}} 0.08$ & \pm 0.02 & 0.86 & \pm 0.19 & ${ }^{a^{\prime}} 0.06$ & \pm 0.01 & 0.75 & \pm 0.10 \\
\hline $18: 2(n-6)$ & b' 0.06 & \pm 0.01 & ab 0.72 & \pm 0.04 & $\mathrm{a}^{\prime} 0.24$ & \pm 0.03 & ${ }^{a} 2.55$ & & $c^{\prime} \quad 0.00$ & \pm 0.00 & ${ }^{b} 0.00$ & & 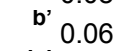 & \pm 0.01 & ab 0.64 & & $\mathbf{b}^{\prime} 0.04$ & & ${ }^{\mathrm{ab}} 0.51$ & \pm 0.09 \\
\hline $18: 4(n-3)$ & $a^{\prime} 0.05$ & \pm 0.01 & 0.55 & \pm 0.14 & $\mathrm{a}^{\prime} 0.05$ & \pm 0.01 & 0.58 & \pm 0.09 & b' 0.02 & \pm 0.00 & 0.21 & \pm 0.00 & 'c' 0.06 & \pm 0.01 & 0.61 & \pm 0.04 & b' 0.02 & \pm 0.01 & 0.22 & \pm 0.08 \\
\hline $20: 2 i$ & $\mathrm{a}^{\prime} 0.02$ & \pm 0.00 & 0.25 & \pm 0.01 & $\mathrm{a}^{\prime} 0.02$ & \pm 0.00 & 0.18 & \pm 0.02 & ${ }^{\text {b' }} 0.04$ & \pm 0.00 & 0.37 & \pm 0.04 & ${ }^{c^{\prime}} 0.03$ & \pm 0.00 & 0.31 & \pm 0.04 & ${ }^{c^{\prime}} 0.03$ & \pm 0.00 & 0.30 & \pm 0.01 \\
\hline 20 :2j & $\mathrm{a}_{0.02}$ & \pm 0.00 & 0.28 & \pm 0.00 & $\mathbf{b}^{\prime} 0.03$ & \pm 0.00 & 0.30 & \pm 0.03 & ${ }^{c^{\prime}} 0.05$ & \pm 0.00 & 0.48 & \pm 0.04 & ${ }^{c^{\prime}} 0.05$ & \pm 0.00 & 0.49 & \pm 0.01 & ${ }^{b^{\prime}} 0.03$ & \pm 0.00 & 0.40 & \pm 0.01 \\
\hline $20: 2(n-6)$ & $\mathrm{a}^{\prime} 0.04$ & \pm 0.00 & ${ }^{\mathrm{ab}} 0.46$ & \pm 0.00 & ${ }^{\prime}{ }^{\prime} 0.13$ & \pm 0.01 & a 1.35 & \pm 0.11 & ${ }^{a} 0.03$ & \pm 0.00 & ${ }^{b} 0.34$ & \pm 0.02 & $a^{\prime} 0.03$ & \pm 0.00 & ${ }^{b} 0.35$ & \pm 0.02 & ${ }^{a^{\prime}} 0.03$ & \pm 0.01 & ${ }^{\mathrm{ab}} 0.39$ & \pm 0.04 \\
\hline $20: 4($ & $\mathrm{a}^{\mathrm{a}^{\prime}} 0.29$ & \pm 0.01 & 3.53 & \pm 0.0 & ${ }^{a} 0.40$ & \pm 0.03 & 4.27 & \pm 0.37 & ${ }^{a} 0.29$ & \pm 0.01 & 3.04 & \pm 0.05 & ${ }^{\mathbf{b}} 0.71$ & \pm 0.11 & 7.36 & \pm 0.53 & ${ }^{a} 0.30$ & & 3.59 & \pm 0.15 \\
\hline $20: 5(n-3$ & $\mathrm{a}^{\prime} \mathbf{c}^{\prime} 1.21$ & \pm 0.06 & 14.54 & \pm 0.0 & $\mathbf{a}^{\prime} \mathbf{b}^{\prime} 1.09$ & \pm 0.04 & 11.47 & \pm 0.32 & c' 1.39 & \pm 0.01 & 14.50 & & $a^{\prime} b^{\prime} 1.08$ & & 11.30 & & ${ }^{b^{\prime}} 0.96$ & & 11.31 & \pm 0.75 \\
\hline $22: 2 i$ & ${ }^{a^{\prime}} 0.07$ & \pm 0.00 & 0.89 & \pm 0.02 & ${ }^{a^{\prime}} 0.07$ & \pm 0.00 & 0.72 & \pm 0.03 & $a^{\prime} 0.07$ & \pm 0.00 & 0.68 & \pm 0.01 & $\mathbf{b}^{\prime} 0.06$ & \pm 0.00 & 0.68 & \pm 0.05 & $\mathrm{a}^{\prime} 0.07$ & \pm 0.00 & 0.88 & \pm 0.04 \\
\hline $22: 2 j$ & $\mathbf{a}^{\prime} \mathbf{b}^{\prime} \quad 0.49$ & \pm 0.00 & 5.90 & \pm 0.20 & b' 0.45 & \pm 0.02 & 4.79 & \pm 0.17 & 'd' 0.66 & \pm 0.02 & 6.89 & \pm 0.29 & $\mathrm{~d}^{\prime} \mathbf{e}^{\prime} \quad 0.60$ & \pm 0.04 & 6.31 & \pm 0.35 & a'e' 0.54 & \pm 0.04 & 6.42 & \pm 0.09 \\
\hline $22: 4(n-6)$ & $\mathrm{a}^{\prime} 0.06$ & \pm 0.00 & 0.76 & \pm 0.03 & b' $^{\prime} 0.08$ & \pm 0.00 & 0.84 & \pm 0.03 & $\mathrm{a}^{\prime} 0.05$ & \pm 0.00 & 0.57 & \pm 0.03 & b' $0.09^{\prime}$ & \pm 0.01 & 0.91 & \pm 0.15 & $\mathrm{a}^{\prime} 0.06$ & \pm 0.01 & 0.73 & \pm 0.05 \\
\hline $22: 5(n-6)$ & ${ }^{a} 0.09$ & \pm 0.00 & 1.09 & \pm 0.00 & $\mathrm{a}^{\prime} 0.09$ & \pm 0.00 & 0.99 & \pm 0.03 & $\mathrm{a}^{\prime} 0.08$ & \pm 0.00 & 0.81 & \pm 0.03 & $\mathrm{a}^{\prime} 0.08$ & \pm 0.01 & 0.86 & \pm 0.05 & 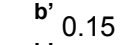 & \pm 0.02 & 1.77 & \pm 0.14 \\
\hline $22: 5(n-3)$ & ${ }^{a} 0.16$ & \pm 0.01 & 1.94 & \pm 0.07 & $\mathbf{a}^{\prime} \mathbf{b}^{\prime} 0.15$ & \pm 0.01 & 1.57 & \pm 0.12 & $\mathrm{a}^{\prime} \mathbf{b}^{\prime} 0.14$ & \pm 0.00 & 1.45 & \pm 0.02 & $\mathrm{a}^{\prime} \mathbf{b}^{\prime} 0.14$ & \pm 0.01 & 1.48 & \pm 0.06 & ${ }^{\text {b' }} 0.13$ & \pm 0.01 & 1.49 & \pm 0.03 \\
\hline $22: 6(n-3)$ & 1.73 & \pm 0.07 & 20.78 & \pm 0.08 & 1.64 & \pm 0.05 & 17.34 & \pm 0.40 & 1.40 & \pm 0.05 & 14.64 & \pm 0.61 & 1.42 & \pm 0.15 & 14.82 & \pm 0.37 & 1.55 & \pm 0.20 & 18.24 & \pm 0.68 \\
\hline TO.M & $\mathbf{a}^{\prime} 1.36$ & \pm 0.04 & 16.37 & \pm 0.17 & $\mathbf{a}^{\prime} 1.36$ & \pm 0.09 & 14.31 & \pm 0.82 & b' $_{1.85}$ & & 19.27 & & $\mathbf{c}^{\prime}{ }_{1.63}$ & & 17.05 & \pm 1.06 & ${ }^{a^{\prime}}{ }_{1.30}$ & & 15.37 & \\
\hline TO. $(\mathrm{n}-$ & 0.29 & \pm 0.01 & & \pm 0 & 0.33 & \pm 0.02 & 3.53 & \pm 0.16 & 0.29 & \pm 0.06 & 3.02 & \pm 0.55 & 0.28 & \pm 0.01 & 2.89 & \pm 0.29 & 0.28 & \pm 0.01 & 3.33 & \pm 0.18 \\
\hline TO.(n-7) & ${ }^{a} 0.82$ & \pm 0.05 & 9.82 & \pm 0.20 & ${ }^{a^{\prime}} 0.70$ & \pm 0.08 & 7.41 & \pm 0.80 & b' $_{1.23}$ & \pm 0.01 & 12.84 & \pm 0.24 & $c^{\prime} 1.06$ & \pm 0.08 & 11.05 & \pm 0.67 & ${ }^{a} 0.77$ & \pm 0.08 & 9.14 & \pm 0.14 \\
\hline TO.P & 4.75 & \pm 0.32 & 57.09 & \pm 1.34 & 4.85 & \pm 0.06 & 51.23 & \pm 0.52 & & & 47.16 & & 4.70 & & 48.95 & \pm 0.27 & 4.18 & & 49.35 & \\
\hline TO.(n-4) & $\mathrm{a}^{\prime} 0.02$ & \pm 0.00 & 0.24 & \pm 0.04 & $\mathrm{a}^{\prime} 0.01$ & \pm 0.00 & 0.14 & \pm 0.02 & b' 0.05 & \pm 0.01 & 0.54 & \pm 0.09 & $c^{\prime} 0.03$ & \pm 0.00 & 0.28 & \pm 0.04 & ${ }^{a} \quad 0.01$ & \pm 0.00 & 0.15 & \pm 0.03 \\
\hline TO.(n-6) & $\mathrm{a}^{\prime} 0.56$ & \pm 0.02 & 6.79 & \pm 0.05 & $\mathbf{b}^{\prime} 1.00$ & \pm 0.06 & 10.57 & \pm 0.76 & ${ }^{a^{\prime}} 0.49$ & \pm 0.01 & 5.10 & & b' $_{1.01}$ & \pm 0.13 & 10.53 & \pm 0.61 & ${ }^{a^{\prime}} 0.61$ & \pm 0.09 & 7.22 & \pm 0.45 \\
\hline TO. $(n-3)$ & 3.56 & 0.29 & 42.73 & \pm 1.65 & 3.27 & \pm 0.12 & 34.53 & \pm 1.03 & 3.17 & \pm 0.06 & 33.07 & \pm 0.96 & 2.91 & \pm 0.26 & 30.35 & \pm 0.30 & 2.88 & \pm 0.40 & 33.99 & \pm 1.60 \\
\hline TO. NMI & $\mathbf{a}^{\prime} \mathbf{b}^{\prime} 0.61$ & \pm 0.01 & 7.32 & \pm 0.21 & b' 0.57 & \pm 0.02 & 5.99 & \pm 0.18 & $c^{\prime} \mathbf{d}^{\prime} \quad 0.81$ & \pm 0.02 & 8.41 & \pm 0.30 & d'e' 0.75 & \pm 0.05 & 7.79 & \pm 0.40 & $\mathrm{a}^{\prime} \mathbf{e}^{\prime} 0.68$ & \pm 0.06 & 8.00 & \pm 0.12 \\
\hline$(n-3) /(n-6)$ & $\mathbf{a}^{\prime} \mathbf{b}^{\prime} 6.29$ & \pm 0.29 & 6.29 & \pm 0.29 & $c^{\prime} 3.28$ & \pm 0.33 & 3.28 & \pm 0.33 & b' 6.49 & \pm 0.28 & 6.49 & \pm 0.28 & $\mathrm{c}^{\prime}{ }_{2.89}$ & \pm 0.19 & 2.89 & \pm 0.19 & d' $_{4.71}$ & \pm 0.15 & 4.71 & \pm 0.15 \\
\hline $22: 6 / 20: 5$ & ${ }^{a^{\prime}} 1.43$ & \pm 0.01 & 1.43 & \pm 0.01 & $\mathrm{a}^{\prime} 1.51$ & \pm 0.02 & 1.51 & \pm 0.02 & b' 1.01 & \pm 0.03 & 1.01 & \pm 0.03 & $\mathrm{c}^{\prime} 1.31$ & \pm 0.07 & 1.31 & \pm 0.07 & d' 1.61 & \pm 0.06 & 1.61 & \pm 0.06 \\
\hline $22: 5 / 20: 4$ & $\mathrm{a}^{\prime} 0.31$ & \pm 0.00 & 0.31 & \pm 0.00 & $\mathbf{b}^{\prime} 0.23$ & \pm 0.03 & 0.23 & \pm 0.03 & b' $^{\prime} 0.27$ & \pm 0.01 & 0.27 & \pm 0.01 & $c^{\prime} 0.12$ & \pm 0.01 & 0.12 & \pm 0.01 & d' 0.49 & \pm 0.03 & 0.49 & \pm 0.03 \\
\hline TOTAL & 8.32 & \pm 0.36 & 100.00 & \pm 0.00 & 9.47 & \pm 0.11 & 100.00 & \pm 0.00 & 9.59 & \pm 0.14 & 100.00 & \pm 0.00 & 9.59 & \pm 0.82 & 100.00 & \pm 0.00 & 8.46 & \pm 0.80 & 100.00 & \pm 0.00 \\
\hline
\end{tabular}




\begin{tabular}{|c|c|c|c|c|c|c|c|c|c|c|c|c|c|c|c|c|c|c|c|c|}
\hline \multirow{3}{*}{ Fatty acid } & & & & & \multicolumn{16}{|c|}{ Oyster diets } \\
\hline & \multicolumn{4}{|c|}{ Initial } & \multicolumn{4}{|c|}{ R. salina } & \multicolumn{4}{|c|}{ T. weissflogii } & \multicolumn{4}{|c|}{ T. pseudonana } & \multicolumn{4}{|c|}{ P. lutheri } \\
\hline & \multicolumn{2}{|c|}{$\begin{array}{l}\text { Contents } \\
\left(\mu \mathrm{g} \mathrm{mg}^{-1}\right)\end{array}$} & \multicolumn{2}{|c|}{$\begin{array}{c}\text { Rel. Contents } \\
(\%)\end{array}$} & \multicolumn{2}{|c|}{$\begin{array}{l}\text { Contents } \\
\left(\mu \mathrm{gg}^{-1}\right)\end{array}$} & \multicolumn{2}{|c|}{$\begin{array}{l}\text { Rel. Contents } \\
(\%)\end{array}$} & \multicolumn{2}{|c|}{$\begin{array}{l}\text { Contents } \\
\left(\mu \mathrm{g} \mathrm{mg}^{-1}\right)\end{array}$} & \multicolumn{2}{|c|}{$\begin{array}{l}\text { Rel. Contents } \\
(\%)\end{array}$} & \multicolumn{2}{|c|}{$\begin{array}{l}\text { Contents } \\
\left(\mu \mathrm{mg}^{-1}\right)\end{array}$} & \multicolumn{2}{|c|}{$\begin{array}{c}\text { Rel. Contents } \\
(\%)\end{array}$} & \multicolumn{2}{|c|}{$\begin{array}{l}\text { Contents } \\
\left(\mu \mathrm{g} \mathrm{mg}^{-1}\right)\end{array}$} & \multicolumn{2}{|c|}{$\begin{array}{l}\text { Rel. Contents } \\
(\%)\end{array}$} \\
\hline $14: 0$ & 0.19 & \pm 0.07 & 0.85 & \pm 0.04 & 0.13 & \pm 0.02 & 0.54 & \pm 0.05 & 0.24 & \pm 0.04 & 0.82 & \pm 0.04 & 0.22 & \pm 0.02 & 0.92 & \pm 0.06 & 0.20 & \pm 0.02 & 0.84 & \pm 0.06 \\
\hline 16:0 & 3.79 & \pm 1.58 & 16.72 & \pm 0.15 & 1.84 & \pm 0.28 & 7.50 & \pm 0.51 & 2.34 & \pm 0.40 & 8.00 & \pm 0.19 & 2.02 & \pm 0.12 & 8.39 & \pm 0.24 & 1.90 & \pm 0.14 & 8.18 & \pm 0.49 \\
\hline 18:0 & 1.41 & \pm 0.61 & 6.20 & \pm 0.04 & 1.28 & \pm 0.17 & 5.22 & \pm 0.33 & 1.22 & \pm 0.14 & 4.18 & \pm 0.10 & 1.07 & \pm 0.05 & 4.43 & \pm 0.08 & 0.97 & \pm 0.06 & 4.18 & \pm 0.32 \\
\hline $16: 1(n-7)$ & $\mathrm{a}^{\prime} 0.19$ & \pm 0.07 & ${ }^{\mathrm{ab}} 0.87$ & \pm 0.06 & $\mathrm{a}^{\prime} 0.12$ & \pm 0.01 & ${ }^{\mathrm{a}} 0.49$ & \pm 0.02 & 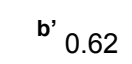 & \pm 0.09 & ${ }^{b} 2.13$ & \pm 0.04 & $\mathbf{c}^{\prime} 0.37$ & \pm 0.02 & ab 1.54 & \pm 0.05 & $\mathrm{a}^{\mathbf{a}^{\prime} \mathbf{d}^{\prime}} 0.23$ & \pm 0.02 & ${ }^{\mathrm{ab}} 0.98$ & \pm 0.07 \\
\hline $18: 1(n-9)$ & 0.39 & \pm 0.18 & 1.69 & \pm 0.05 & 0.27 & \pm 0.03 & 1.11 & \pm 0.01 & 0.33 & \pm 0.03 & 1.13 & \pm 0.06 & 0.25 & \pm 0.02 & 1.05 & \pm 0.11 & 0.31 & \pm 0.01 & 1.33 & \pm 0.05 \\
\hline $18: 1(n-7)$ & $a^{a d d} 0.26$ & \pm 0.10 & 1.13 & \pm 0.03 & ${ }^{a^{\prime}} 0.12$ & \pm 0.02 & 0.50 & \pm 0.05 & ${ }^{b^{\prime}}, 0.65$ & \pm 0.14 & 2.23 & \pm 0.13 & 'd' 0.40 & \pm 0.03 & 1.68 & \pm 0.09 & ${ }^{d^{\prime}} 0.33$ & \pm 0.03 & 1.43 & \pm 0.09 \\
\hline $16: 3(n-3)$ & $\mathrm{a}^{\prime} 0.80$ & \pm 0.02 & 3.90 & \pm 1.73 & ${ }^{\text {b' }} 0.12$ & \pm 0.01 & 0.47 & \pm 0.05 & ${ }^{b^{\prime}} 0.23$ & \pm 0.11 & 0.82 & \pm 0.44 & ${ }^{b^{\prime}} 0.23$ & \pm 0.04 & 0.94 & \pm 0.13 & b'$^{\prime} 0.15$ & \pm 0.01 & 0.67 & \pm 0.04 \\
\hline $18: 2(n-6)$ & ${ }^{a} 0.14$ & \pm 0.06 & ${ }^{\mathrm{a}} 0.63$ & \pm 0.02 & b' 0.59 & \pm 0.12 & b 2.40 & \pm 0.28 & $a^{\prime} 0.00$ & \pm 0.00 & ${ }^{c} 0.00$ & \pm 0.00 & ${ }^{a^{\prime}} 0.09$ & \pm 0.01 & ${ }^{\mathrm{ac}} 0.37$ & \pm 0.01 & ${ }^{a^{\prime}} 0.08$ & \pm 0.01 & ac $^{\prime} 0.36$ & \pm 0.04 \\
\hline $18: 4(n-3)$ & ${ }^{a} 0.07$ & \pm 0.02 & 0.35 & \pm 0.07 & ${ }^{a}=0.07$ & \pm 0.02 & 0.28 & \pm 0.06 & ${ }^{\prime}{ }^{\prime} 0.02$ & \pm 0.00 & 0.08 & \pm 0.01 & $\mathrm{a}^{\prime} \mathrm{c}^{\prime} 0.07$ & \pm 0.01 & 0.29 & \pm 0.03 & b'd' $^{\prime} 0.02$ & \pm 0.00 & 0.10 & \pm 0.02 \\
\hline $20: 2 i$ & ${ }^{a}, 0.12$ & \pm 0.05 & 0.53 & \pm 0.01 & ${ }^{\mathbf{a}^{\prime}} 0.06$ & \pm 0.00 & 0.24 & \pm 0.02 & ${ }^{\prime}{ }^{\prime} 0.23$ & \pm 0.05 & 0.77 & \pm 0.09 & $\mathrm{a}^{\mathrm{a}} 0.13$ & \pm 0.01 & 0.56 & \pm 0.04 & $\mathrm{a}^{\prime} 0.14$ & \pm 0.01 & 0.60 & \pm 0.07 \\
\hline $20: 2 j$ & ${ }^{a} 0.06$ & \pm 0.02 & bc 0.26 & \pm 0.00 & $a^{\prime} b^{\prime} 0.04$ & \pm 0.01 & ${ }^{a} 0.16$ & \pm 0.02 & ${ }^{\prime} \quad 0.17$ & \pm 0.03 & ${ }^{b} 0.58$ & \pm 0.02 & c'd' 0.15 & \pm 0.00 & ${ }^{b c} 0.60$ & \pm 0.03 & ${ }^{\text {e' }} 0.10$ & \pm 0.00 & 0.43 & \pm 0.01 \\
\hline $20: 2(n-6)$ & $a^{\prime} 0.05$ & \pm 0.02 & ${ }^{a} 0.20$ & \pm 0.00 & ${ }^{b^{\prime}} 0.24$ & \pm 0.04 & ${ }^{b} 0.97$ & \pm 0.13 & ${ }^{a}, 0.06$ & \pm 0.01 & ${ }^{\mathrm{a}} 0.20$ & \pm 0.01 & ${ }^{a}, 0.02$ & \pm 0.00 & ${ }^{a} 0.10$ & \pm 0.01 & ${ }^{a^{\prime}} 0.04$ & \pm 0.00 & ${ }^{a} 0.18$ & \pm 0.02 \\
\hline $20: 4(n-6)$ & ${ }^{a}, 1.47$ & \pm 0.64 & ${ }^{\mathrm{ab}} 6.49$ & \pm 0.05 & ${ }^{a} 1.98$ & \pm 0.13 & ${ }^{\mathrm{a}} 8.11$ & \pm 0.24 & $\mathrm{a}^{\prime} 1.25$ & \pm 0.18 & ${ }^{b} 4.29$ & \pm 0.07 & ${ }^{b^{\prime}} 3.34$ & \pm 0.24 & ${ }^{c}{ }_{13.86}$ & \pm 0.53 & ${ }^{a^{\prime}} 1.32$ & \pm 0.07 & a b 5.69 & \pm 0.18 \\
\hline $20: 5(n-3)$ & a' 2.22 & \pm 0.96 & 9.75 & \pm 0.07 & ${ }^{a} 2.08$ & \pm 0.26 & 8.50 & \pm 0.35 & b' 4.21 & \pm 0.71 & 14.40 & \pm 0.55 & ${ }^{\text {a' }} 1.49$ & \pm 0.10 & 6.18 & \pm 0.22 & a' 1.71 & \pm 0.12 & 7.37 & \pm 0.36 \\
\hline $22: 2 i$ & $\mathbf{a}^{\prime} \mathbf{b}^{\prime} 0.39$ & \pm 0.17 & 1.72 & \pm 0.03 & b'c' $^{\prime} 0.22$ & \pm 0.02 & 0.89 & \pm 0.08 & 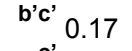 & \pm 0.02 & 0.58 & \pm 0.03 & ${ }^{c} 0.16$ & \pm 0.01 & 0.68 & \pm 0.03 & b'c' $^{\prime} 0.24$ & \pm 0.01 & 1.04 & \pm 0.04 \\
\hline $22: 2 j$ & b'c' $^{\prime} 2.28$ & \pm 1.01 & 10.03 & \pm 0.16 & $\mathbf{a}^{\prime} \mathbf{b}^{\prime} 1.28$ & \pm 0.13 & 5.25 & \pm 0.63 & c' 3.37 & \pm 0.47 & 11.57 & \pm 0.55 & b'c' $^{\prime} 2.33$ & \pm 0.02 & 9.66 & \pm 0.25 & b'c' $^{\prime} 2.35$ & \pm 0.09 & 10.15 & \pm 0.40 \\
\hline $22: 4(n-6)$ & $a^{\prime} 0.20$ & \pm 0.08 & ${ }^{\mathrm{ab}} 0.89$ & \pm 0.02 & $\mathbf{b}^{\prime} 0.27$ & \pm 0.02 & ab 1.09 & \pm 0.03 & ${ }^{a} 0.14$ & \pm 0.01 & ${ }^{\mathrm{a}} 0.49$ & \pm 0.03 & ${ }^{\prime}{ }^{\prime} 0.47$ & \pm 0.03 & b 1.95 & \pm 0.05 & $\mathbf{a}^{\prime} \mathbf{b}^{\prime} 0.17$ & \pm 0.01 & ${ }^{\mathrm{ac}} 0.73$ & \pm 0.02 \\
\hline $22: 5(n-6)$ & $\mathrm{a}^{\prime} 0.37$ & \pm 0.15 & ab 1.64 & \pm 0.03 & $\mathrm{a}^{\prime} 0.22$ & \pm 0.02 & ${ }^{\mathrm{a}} 0.91$ & \pm 0.07 & $\mathrm{a}^{\mathrm{\prime} \mathrm{c}^{\prime}} 0.17$ & \pm 0.02 & ${ }^{\mathrm{a}} 0.59$ & \pm 0.03 & ${ }^{a} 0.21$ & \pm 0.00 & ${ }^{\mathrm{a}} 0.86$ & \pm 0.03 & ${ }^{\mathbf{b}^{\prime}} 0.85$ & \pm 0.05 & ${ }^{\text {b }} 3.68$ & \pm 0.29 \\
\hline $22: 5(n-3)$ & 0.29 & \pm 0.12 & 1.28 & \pm 0.01 & 0.26 & \pm 0.02 & 1.07 & \pm 0.00 & 0.31 & \pm 0.05 & 1.06 & \pm 0.06 & 0.21 & \pm 0.01 & 0.85 & \pm 0.02 & 0.16 & \pm 0.01 & 0.68 & \pm 0.05 \\
\hline $22: 6(n-3)$ & 3.70 & \pm 1.60 & 16.26 & \pm 0.13 & 3.79 & \pm 0.40 & 15.49 & \pm 0.36 & 3.24 & \pm 0.55 & 11.07 & \pm 0.61 & 2.61 & \pm 0.20 & 10.82 & \pm 0.48 & 3.23 & \pm 0.11 & 13.91 & \pm 0.18 \\
\hline TOMONO & $a^{\prime} \mathbf{b}^{\prime} 3.25$ & \pm 1.23 & 14.50 & \pm 0.77 & 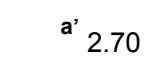 & \pm 0.31 & 11.04 & \pm 0.36 & b' $_{4.67}$ & \pm 0.63 & 16.01 & \pm 0.24 & $\mathbf{a}^{\prime} \mathbf{b}^{\prime} 3.57$ & \pm 0.07 & 14.81 & \pm 0.22 & $\mathbf{a}^{\prime} \mathbf{b}^{\prime} 3.02$ & \pm 0.10 & 13.04 & \pm 0.25 \\
\hline TO.(n-9) & 0.50 & \pm 0.14 & 2.30 & \pm 0.38 & 0.59 & \pm 0.07 & 2.42 & \pm 0.09 & 0.52 & \pm 0.04 & 1.79 & \pm 0.12 & 0.42 & \pm 0.03 & 1.75 & \pm 0.20 & 0.49 & \pm 0.01 & 2.10 & \pm 0.03 \\
\hline TO.(n-7) & $\mathrm{a}^{\prime} 1.77$ & \pm 0.75 & ${ }^{\mathrm{ab}} 7.79$ & \pm 0.03 & $\mathrm{a}^{\prime} 1.12$ & \pm 0.08 & ${ }^{\mathrm{a}} 4.58$ & \pm 0.12 & $\mathbf{b}^{\prime} 2.99$ & \pm 0.45 & $b_{10.23}$ & \pm 0.13 & ${ }^{a^{\prime} \mathbf{b}^{\prime}} 2.17$ & \pm 0.09 & ${ }^{a b} 9.02$ & \pm 0.14 & $\mathrm{a}^{\prime}{ }_{1.65}$ & \pm 0.09 & ${ }^{a b} 7.10$ & \pm 0.27 \\
\hline TO.POLY & 12.70 & \pm 5.15 & 56.25 & \pm 1.28 & 12.48 & \pm 1.11 & 51.12 & \pm 0.27 & 14.05 & \pm 2.06 & 48.14 & \pm 0.14 & 11.87 & \pm 0.68 & 49.22 & \pm 1.16 & 11.57 & \pm 0.32 & 49.91 & \pm 0.34 \\
\hline TO.(n-4) & $a^{\prime}, 0.08$ & \pm 0.02 & 0.39 & \pm 0.08 & $\mathbf{b}^{\prime} \mathbf{d}^{\prime} \quad 0.02$ & \pm 0.00 & 0.09 & \pm 0.01 & $a^{a^{\prime} c^{\prime}} 0.08$ & \pm 0.03 & 0.29 & \pm 0.09 & $c^{c} d^{\prime}, 0.05$ & \pm 0.01 & 0.21 & \pm 0.04 & ${ }^{\text {d' }} 0.03$ & \pm 0.00 & 0.14 & \pm 0.01 \\
\hline TO.(n-6) & 'b' 2.28 & \pm 0.95 & bc 10.05 & \pm 0.08 & $\mathrm{a}^{\prime} \mathbf{c}^{\prime} 3.38$ & \pm 0.31 & ${ }^{a} 13.85$ & \pm 0.15 & 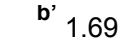 & \pm 0.24 & ${ }^{\mathbf{b}} 5.80$ & \pm 0.09 & $\mathrm{c}^{\prime} 4.20$ & \pm 0.27 & ${ }^{\mathrm{ac}} 17.41$ & \pm 0.54 & $\mathbf{a}^{\prime} \mathbf{b}^{\prime} 2.51$ & \pm 0.06 & ${ }^{a b} 10.82$ & \pm 0.18 \\
\hline TO.(n-3) & 7.49 & \pm 2.92 & 33.28 & \pm 1.31 & 7.48 & \pm 0.79 & 30.63 & \pm 0.77 & 8.31 & \pm 1.28 & 28.48 & \pm 0.75 & 4.83 & \pm 0.37 & 20.03 & \pm 0.86 & 6.20 & \pm 0.24 & 26.71 & \pm 0.45 \\
\hline TO. NMI & $a^{a^{\prime} b^{\prime}} 2.85$ & \pm 1.26 & 12.54 & \pm 0.19 & $\mathrm{a}^{\prime} 1.59$ & \pm 0.16 & 6.54 & \pm 0.75 & 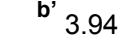 & \pm 0.56 & 13.51 & \pm 0.64 & $\mathrm{a}^{\prime} \mathbf{b}^{\prime} 2.77$ & \pm 0.02 & 11.50 & \pm 0.33 & $a^{a} b^{\prime} 2.84$ & \pm 0.09 & 12.23 & \pm 0.37 \\
\hline$(n-3) /(n-6)$ & $\mathbf{a}^{\prime} 3.31$ & \pm 0.10 & ${ }^{a b} 3.31$ & \pm 0.10 & ${ }^{\mathbf{b}} 2.21$ & \pm 0.04 & ${ }^{a c} 2.21$ & \pm 0.04 & c' 4.91 & \pm 0.06 & b 4.91 & \pm 0.06 & ${ }^{d^{\prime}} 1.15$ & \pm 0.02 & $c_{1.15}$ & \pm 0.02 & $\mathbf{e}_{2.47}^{\prime}$ & \pm 0.07 & ${ }^{a b c} 2.47$ & \pm 0.07 \\
\hline $22: 6 / 20: 5$ & ${ }^{a} 1.67$ & \pm 0.00 & 1.67 & \pm 0.00 & $\mathbf{e}^{\prime} \mathbf{b}^{\prime} 1.82$ & \pm 0.03 & 1.82 & \pm 0.03 & $c^{\prime} d^{\prime} 0.77$ & \pm 0.02 & 0.77 & \pm 0.02 & 'b'd' 1.75 & \pm 0.07 & 1.75 & \pm 0.07 & $\mathbf{e}^{\prime} 1.89$ & \pm 0.07 & 1.89 & \pm 0.07 \\
\hline $22: 5 / 20: 4$ & $\mathrm{a}^{\prime} 0.25$ & \pm 0.01 & ${ }^{\mathrm{ab}} 0.25$ & \pm 0.01 & 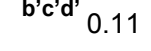 & \pm 0.01 & ${ }^{\mathrm{a}} 0.11$ & \pm 0.01 & $\mathrm{c}^{\prime} 0.14$ & \pm 0.01 & ${ }^{\mathrm{a}} 0.14$ & \pm 0.01 & $\mathrm{~d}^{\mathrm{d}^{\prime}} 0.06$ & \pm 0.00 & ${ }^{\mathrm{a}} 0.06$ & \pm 0.00 & ${ }^{e^{\prime}} 0.65$ & \pm 0.07 & ${ }^{\mathrm{a}} 0.65$ & \pm 0.07 \\
\hline TOTAL & 22.69 & \pm 9.67 & 100.00 & \pm 0.00 & 24.41 & \pm 2.21 & 100.00 & \pm 0.00 & 29.17 & \pm 4.23 & 100.00 & \pm 0.00 & 24.10 & \pm 0.83 & 100.00 & \pm 0.00 & 23.19 & \pm 0.51 & 100.00 & \pm 0.00 \\
\hline
\end{tabular}


les

Table 6 sanalysys

\begin{tabular}{|c|c|c|c|c|c|c|c|c|c|c|c|c|c|c|c|c|}
\hline \multirow{3}{*}{ Fatty acid } & \multicolumn{16}{|c|}{ Oyster organs } \\
\hline & \multicolumn{4}{|c|}{ Gonad } & \multicolumn{4}{|c|}{ Digestive gland } & \multicolumn{4}{|c|}{ Muscle } & \multicolumn{4}{|c|}{ Gills } \\
\hline & \multicolumn{2}{|c|}{$\begin{array}{c}\text { Initial Contents } \\
(\%)\end{array}$} & \multicolumn{2}{|c|}{$\begin{array}{c}\text { Final Contents } \\
(\%)\end{array}$} & \multicolumn{2}{|c|}{$\begin{array}{l}\text { Initial Contents } \\
(\%)\end{array}$} & \multicolumn{2}{|c|}{$\begin{array}{c}\text { Final Contents } \\
(\%)\end{array}$} & \multicolumn{2}{|c|}{$\begin{array}{l}\text { Initial Contents } \\
(\%)\end{array}$} & \multicolumn{2}{|c|}{$\begin{array}{c}\text { Final Contents } \\
(\%)\end{array}$} & \multicolumn{2}{|c|}{$\begin{array}{l}\text { Initial Contents } \\
(\%)\end{array}$} & \multicolumn{2}{|c|}{$\begin{array}{l}\text { Final Contents } \\
(\%) \\
\end{array}$} \\
\hline $14: 0$ & 1.16 & \pm 0.88 & n.d. & n.d. & 1.37 & \pm 0.16 & 1.01 & \pm 0.22 & 1.02 & \pm 0.04 & 0.81 & \pm 0.06 & 0.85 & \pm 0.04 & 0.56 & \pm 0.07 \\
\hline 16:0 & 20.70 & \pm 1.25 & n.d. & n.d. & 18.12 & \pm 0.61 & 16.37 & \pm 0.90 & 16.30 & \pm 0.11 & * 9.89 & \pm 0.22 & 16.72 & \pm 0.15 & * 7.42 & \pm 0.25 \\
\hline 18:0 & 6.59 & \pm 0.45 & n.d. & n.d. & 6.75 & \pm 0.23 & 6.43 & \pm 0.06 & 6.22 & \pm 0.24 & 6.20 & \pm 0.23 & 6.20 & \pm 0.04 & 5.27 & \pm 0.42 \\
\hline $20: 4(n-6)$ & 3.41 & \pm 1.01 & n.d. & n.d. & 4.86 & \pm 0.11 & 6.72 & \pm 0.78 & 3.53 & \pm 0.04 & 4.05 & \pm 0.25 & 6.49 & \pm 0.05 & 6.78 & \pm 0.16 \\
\hline $20: 5(n-3)$ & 11.74 & \pm 2.33 & n.d. & n.d. & 11.45 & \pm 0.36 & 11.98 & \pm 0.60 & 14.54 & \pm 0.08 & 12.04 & \pm 0.60 & 9.75 & \pm 0.07 & 8.77 & \pm 0.42 \\
\hline $22: 6(n-3)$ & 15.93 & \pm 2.89 & n.d. & n.d. & 16.07 & \pm 0.46 & 17.41 & \pm 1.02 & 20.78 & \pm 0.08 & 19.00 & \pm 1.24 & 16.26 & \pm 0.13 & 15.84 & \pm 0.65 \\
\hline$\sum$ PUFA & 50.69 & \pm 3.58 & n.d. & n.d. & 52.95 & \pm 1.02 & 58.53 & \pm 2.06 & 57.09 & \pm 1.34 & 50.77 & \pm 0.07 & 56.25 & \pm 1.28 & 51.38 & \pm 0.39 \\
\hline
\end{tabular}


Gonad

Brassicasterol

Cholesterol Campesterol

24-Methylencholesterol

Stigmastérol

Isofucosterol

MethylPorifera

$\beta$-sitosterol

Fucosterol

Desmosterol

MethylPavlovol

EthylPavlovol

\section{Digestive gland}

Brassicasterol Cholesterol

Campesterol

24-Methylen-

cholestero

Stigmastérol

Isofucosterol

MethylPorifera

$\beta$-sitosterol

Fucosterol

Desmostero

MethylPavlovol

EthylPavlovol

\section{Muscle}

Brassicasterol Cholesterol

Campesterol

24-Methylencholesterol

Stigmastérol

Isofucosterol

MethylPorifera

$\beta$-sitosterol

Fucosterol

Desmostero

MethylPavlovo

EthylPavlovol

Gills

Brassicasterol

Cholesterol

Campesterol

24-Methylen-

cholesterol

Stigmastéro

Isofucosterol

MethylPorifera

$\beta$-sitosterol

Fucosterol

Desmostero

MethylPavlovol

EthylPavlovol
$19.3 \pm 0.2$

$33.8 \pm 0.3$

${ }^{\mathrm{a}} 2.4 \pm 0.0$

$14.1 \pm 0.5$

$4.1 \pm 0.5$

$2.5 \pm 0.2$

$1.9 \pm 0.1$

ab $4.3 \pm 0.1$

a $3.7 \pm 0.1$

${ }^{\text {a }} 5.0 \pm 0.2$

$0.0 \pm 0.0$

$0.0 \pm 0.0$

$45.0 \quad \pm 7.7$

$26.3 \pm 3.4$

${ }^{\mathrm{a}} 2.4 \pm 0.2$

$8.6 \pm 0.9$

$49.2 \pm 1.7$

a $1.6 \pm 0.1$

$9.5 \pm 0.9$

$10.4 \pm 0.4$

$4.0 \pm 1.0$

$2.7 \pm 0.6$

$0.4 \pm 0.1$

a $1.8 \pm 0.6$

a $0.5 \pm 0.1$

b $0.9 \pm 0.2$

$0.0 \pm 0.0$

$0.0 \pm 0.0$

$2.1 \pm 0.3$

$4.1 \pm 0.4$

$0.0 \pm 0.0$

ab $2.0 \pm 0.1$

b $15.0 \pm 1.0$

b $0.8 \pm 0.1$

$0.0 \pm 0.0$

$0.0 \pm 0.0$

$20.3 \pm 0.4$

$35.3 \pm 0.8$

$2.5 \pm 0.0$

ab $16.6 \pm 0.1$

$3.1 \pm 0.2$

$3.0 \pm 0.3$

$1.5 \pm 0.2$

$3.6 \pm 0.3$

$1.8 \pm 0.1$

$2.2 \pm 0.2$

$0.0 \pm 0.0$

$0.0 \pm 0.0$

$32.9 \pm 2.9$

$33.2 \pm 1.4$

$15.0 \pm 0.4$

$1.9 \pm 0.0$

b $13.3 \pm 1.0$

$3.4 \pm 0.9$

$2.7 \pm 0.1$

$0.8 \pm 0.7$

$2.8 \pm 0.6$

$1.0 \pm 0.0$

$0.9 \pm 0.2$

$0.0 \pm 0.0$

$0.0 \pm 0.0$

$31.8 \pm 0.3$

$7.6 \pm 0.3$

$26.1 \pm 0.4$

$3.8 \pm 0.8$

$2.9 \pm 0.2$

$0.9 \pm 0.1$

$3.6 \pm 0.3$

$2.1 \pm 0.2$

$0.7 \pm 0.2$

$0.0 \pm 0.0$

$0.0 \pm 0.0$

$11.3 \pm 9.5$

$25.5 \pm 3.2$

${ }^{\text {b }} 22.4 \pm 2.2$

$16.7 \pm 1.1$

$0.0 \pm 0.0$

$2.5 \pm 0.6$

$5.2 \pm 6.2$

b $9.5 \pm 0.8$

a $0.9 \pm 0.5$

b $1.0 \pm 0.1$

$0.0 \pm 0.0$

$0.0 \pm 0.0$

$13.5 \pm 1.0$

$30.1 \pm 0.8$

$3.5 \pm 0.2$

c $35.9 \pm 0.9$

$3.9 \pm 0.7$

$2.5 \pm 1.2$

$0.8 \pm 0.1$

$2.2 \pm 0.3$

$1.3 \pm 0.6$

$0.7 \pm 0.1$

$0.0 \pm 0.0$

$0.0 \pm 0.0$

$16.1 \pm 0.5$

$32.0 \pm 1.1$

${ }^{\mathrm{a}} 6.0 \pm 0.5$

$16.8 \pm 0.7$

$2.9 \pm 1.0$

$6.8 \pm 0.8$

$0.6 \pm 0.3$

ab $4.7 \pm 0.2$

a $1.0 \pm 0.1$

b $0.9 \pm 0.2$

$0.0 \pm 0.0$

$0.0 \pm 0.0$

$18.5 \pm 0.5$

$35.2 \pm 1.0$

$2.9 \pm 0.9$

b $13.2 \pm 0.8$

$4.6 \pm 0.1$

$2.9 \pm 0.9$

$1.1 \pm 0.1$

$10.7 \pm 1.7$

$1.6 \pm 0.1$

$1.1 \pm 0.2$

$0.0 \pm 0.0$

$0.0 \pm 0.0$

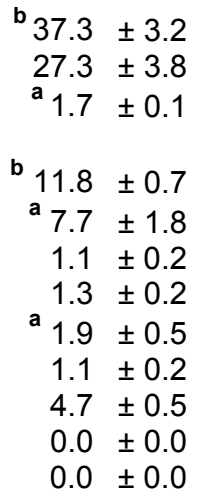

$$
\begin{aligned}
{ }^{a} 9.3 & \pm 0.2 \\
27.6 & \pm 0.4 \\
\mathbf{b} 14.0 & \pm 0.5 \\
\text { ac } & \\
31.8 & \pm 1.0 \\
\text { b } 0.0 & \pm 0.0 \\
1.2 & \pm 0.5 \\
1.5 & \pm 0.1 \\
\text { a } & \pm 0.6 \\
3.1 & \pm 0.1 \\
3.6 & \pm 0.2 \\
0.0 & \pm 0.0 \\
0.0 & \pm 0.0
\end{aligned}
$$

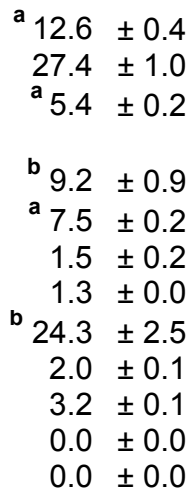


Table 8:

\begin{tabular}{|c|c|c|c|c|c|}
\hline \multirow[b]{2}{*}{$\begin{array}{l}\text { Broodstock } \\
\text { diet }\end{array}$} & \multicolumn{5}{|c|}{ Stages of gonad maturation } \\
\hline & 0 & 1 & 2 & 3 & 4 \\
\hline Initial & 50.0 & 17.0 & 0.0 & 0.0 & 33.0 \\
\hline R. salina & 0.0 & 3.5 & 3.5 & 51.7 & 41.3 \\
\hline T. weissflogii & 6.5 & 9.7 & 16.1 & 61.3 & 6.4 \\
\hline$T$ & 24.2 & 18.2 & 6.1 & 48.5 & 3.0 \\
\hline pseudonana & & & & & \\
\hline P. lutheri & 40.0 & 23.1 & 20.0 & 6.9 & 10.0 \\
\hline
\end{tabular}

